Canadian

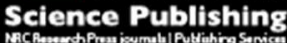

Biochemistry and Cell Biology Biochimie et biologie cellulaire

\title{
Biocidal activity of chicken defensin-9 against microbial pathogens
}

\begin{tabular}{|r|l|}
\hline Journal: & Biochemistry and Cell Biology \\
\hline Manuscript ID & bcb-2015-0121.R1 \\
\hline Manuscript Type: & Article \\
\hline Date Submitted by the Author: & $17-$-Nov-2015 \\
\hline Complete List of Authors: & $\begin{array}{l}\text { Yacoub, Haitham; King Abdulaziz University } \\
\text { El-Hamidy, Salem ; King Abdulaziz University } \\
\text { Mahmoud, Maged ; King Abdulaziz University, King Fahd Medical Research } \\
\text { Center } \\
\text { Baeshen, Mohamed ; King Abdulaziz University } \\
\text { Almehdar, Hussein ; King Abdulaziz University } \\
\text { Uversky, Vladimir; University of South Florida, Molecular Medicine } \\
\text { Redwan, Elrashdy ; King Abdulaziz University } \\
\text { Elazzazy, Ahmed ; University of Jeddah, Biological Sciences Department }\end{array}$ \\
\hline Keyword: & $\begin{array}{l}\text { defensin, antibacterial peptide, antifungal peptide, synthetic defensin, host } \\
\text { defense peptide }\end{array}$ \\
\hline & \\
\hline
\end{tabular}

\section{SCHOLARONE"}

Manuscripts 


\section{Biocidal activity of chicken defensin-9 against microbial pathogens}

Haitham A. Yacoub, ${ }^{1,2, *}$ Salem M. El-Hamidy, ${ }^{3}$ Maged M. Mahmoud, ${ }^{4,5}$ Mohamed Nabih Baeshen ${ }^{1,3}$, Hussein A. Almehdar, ${ }^{3}$ Vladimir N. Uversky, ${ }^{3,6,7, *}$ Elrashdy M. Redwan, $^{3,8, *}$, Omar.A.Al-Maghrabi ${ }^{1}$, and Ahmed M. Elazzazy ${ }^{1,9}$

${ }^{1}$ Biological Sciences Department, Faculty of Science, University of Jeddah, Jeddah, Saudi Arabia \& Department of Biological Sciences, Faculty of Sciences, King Abdulaziz University, P.O. Box 80203, Jeddah, Saudi Arabia.

${ }^{2}$ Cell Biology Department, Genetic Engineering and Biotechnology Division, National Research Centre, Dokki, Gizza, P.O. Box 12622, Egypt

${ }^{3}$ Department of Biological Sciences, Faculty of Sciences, King Abdulaziz University, P.O. Box 80203, Jeddah, Saudi Arabia

${ }^{4}$ King Fahd Medical Research Center, King Abdulaziz University, P.O. Box 80216, Jeddah 21589, Saudi Arabia

${ }^{5}$ Department of Molecular Genetics and Enzymology, Davison of Human Genetics and Genome Research, National Research Centre, Dokki, Gizza, P.O. Box 12622, Egypt;

${ }^{6}$ Institute for Biological Instrumentation, Russian Academy of Sciences, 142290 Pushchino, Moscow Region, Russia;

${ }^{7}$ Therapeutic and Protective Proteins Laboratory, Protein Research Department, Genetic Engineering and Biotechnology Research Institute, City for Scientific Research and Technology Applications, New Borg EL-Arab 21934, Alexandria, Egypt;

${ }^{8}$ Department of Molecular Medicine and USF Health Byrd Alzheimer's Research Institute, Morsani College of Medicine, University of South Florida, Tampa, FL, USA;

${ }^{9}$ Department of Chemistry of Natural and Microbial Products, Division of Pharmaceutical and Drug Industries, National Research Centre, Dokki, Gizza, P.O. Box 12622, Egypt.

*Corresponding authors: Yacoub, H.A. (Haithamyacoub46@gmail.com), Redwan, E.M. (redwan1961@yahoo.com), Uversky, V.N. (vuversky@,health.usf.edu). 


\begin{abstract}
In this study we identified the expression patterns of $\beta$-defensin-9 in local chicken from Saudi Arabia, evaluated antimicrobial activities of the synthetic chicken $\beta$-defensin-9 (sAvBD-9) against pathogenic bacteria and fungi, and investigated the mode of sAvBD-9 action on the bacterial cells. The $A v B D-9$ gene of the local Saudi chicken encodes a polypeptide of 67 amino acids, which is highly similar to the duck, quail, and goose polypeptides $(97 \%, 86 \%$, and $87 \%$, respectively) and shares a low sequence similarity with the mammalian defensins. AvBD-9 is expressed in various organs and tissues of the local chicken and is able to inhibit the growth of both Gram-negative and Gram-positive bacteria, as well as is active against unicellular and multicellular fungi, Aspergillus flavus, Aspergillus niger, and Candida albicans. The sAvBD-9 completely inhibited the growth of both Gram-positive and Gramnegative bacterial strains as well as Candida albicans. The haemolytic effects of sAvBD-9 were limited. The morphological analysis by TEM revealed that SAvBD-9 induces shortening and swelling of Staphylococcus aureus and Shigella sonni cells, opens holes and deep craters in their envelopes, and leads to the release of their cytoplasmic content. Our data shed light on the potential applications of sAvBD-9 in the pharmaceutical industry.
\end{abstract}

Keywords: defensin; antibacterial peptide; antifungal peptide; synthetic defensin 


\section{Introduction}

Many representatives of the family of antimicrobial peptides are frequently found in various living organisms including mammalian, avian, plant, and insect species. These peptides display pronounced antimicrobial potentials against broad spectrum of microorganism, such as bacteria, fungi, parasites, and viruses. Such peptides are known now as host defense peptides (HDPs). The name reflects the involvement of these peptides in the immunomodulation, which is a relatively recent addition to their longer known functions related to the control and inhibition of the microbial growth (Cuperus et al. 2013; Sugiarto and $\mathrm{Yu}$ 2004). These peptides have a short amino acid chain that is typically less than 100 residues. They are cationic molecules rich in arginine, lysine, and histidine. HDPs are amphipathic entities containing hydrophobic and hydrophilic regions. They serve as ancient defense pathways against various kinds of pathogenic agents. Currently, full sequences and phylogenies of defensin and cathelicidin genes have been established for avian species. In addition, there are several studies aiming to figure out the potential use of these peptides as templates for the novel anti-microbial agents (Cuperus et al. 2013).

Defensins are cysteine-rich antimicrobial peptides with six conserved cysteine residues that form three pairs of disulfide bridges. In vertebrates (including avian species), there are several types of defensins, which are classified into three sub-clusters, $\alpha$-defensins, $\beta$ defensins, and $\theta$-defensins, based on their length and distribution of the cysteine residues that form the disulfide bridges (Sugiarto and Yu 2004; Yacoub et al. 2015; Yacoub et al. 2011). $\alpha$ Defensins are found in mammals (Lehrer and Ganz 2002), $\theta$-defensins are present in all vertebrates (Klotman and Chang 2006; Lehrer and Ganz 2002), whereas avian species are characterized by the presence of $\beta$-defensins (Cuperus et al. 2013). Most defensins, and particularly avian $\beta$-defensins, are known to exhibit an effective antimicrobial activity against a broad spectrum of pathogens including bacteria and fungi. 
The actual mechanisms defining the ability of these $\beta$-defensins to inactive and kill pathogenic agents are not fully understood. However, several studies supported the hypothesis that the action of these peptides is depended on two major features, their cationic and amphipathic properties (Evans and Harmon 1995; Powers and Hancock 2003). Many studies concluded that the action of $\beta$-defensins begins with the attachment of this peptide to bacterial membrane through the electrostatic interaction between the negatively charged bacterial membrane and the exposed cationic sites of the $\beta$-defensins. These defensinmembrane interactions result in the formation of hollow defensin-based channels penetrating the phospholipid bilayer that eventually leads to the membrane disruption (Brogden 2005; Ganz 2004; Powers and Hancock 2003; Sugiarto and Yu 2004; Zasloff 2002). The aims of the study were to identify the expression patterns of the $\beta$-defensin- 9 in local Saudi chicken, to evaluate the antimicrobial activities of the synthetic avian $\beta$-defensin-9 (sAvBD-9) against pathogenic bacteria and fungi, and to investigate the mode of the sAvBD-9 action on the bacterial cells using transmission electron microscopy (TEM).

\section{Materials and methods}

\section{Animals}

Fifty healthy local Saudi chicken used in this study were obtained from the King Abdulaziz University farm, Jeddah, Saudi Arabia. The birds were kept in cages and provided with water and food ad libitum.

\section{Tissue collection}

Tissue specimens were collected from nineteen organs of the local Saudi chicken including 
bone marrow, spleen, liver, oviduct, ovum, large and small intestines, pancreas, skin, egg yolk, muscles, heart, testis, duodenum, gizzard, uterus, and kidney. These tissues were dissected and frozen in liquid nitrogen until used.

\section{RNA isolation and cDNA synthesis}

Total RNAs were isolated from 30-60 mg of bone marrow, spleen, liver, oviduct, ovum, large and small intestines, pancreas, skin, egg yolk, muscles, heart, testis, duodenum, gizzard, uterus, and kidney tissues using EZ RNA Clean Up Plus DNase Kit (EZ BioResearch, St Louis, MO, USA). RNA concentrations were measured using NanoDrop Spectrophotometer (Jenway, UK). Reverse transcriptions (RT) was performed using oligo-dT primers (Bioneer Inc, Daejeon, Republic of Korea) in a $20 \mu \mathrm{L}$ reaction including $5 \mu \mathrm{L}$ RNA. The cDNAs obtained were amplified by using PCR Master Mix (Bioneer Inc, Daejeon, Korea) with primers designed by (Ma et al. 2012c) as shown in Table 1. PCR amplification reactions were performed in a $50 \mu \mathrm{L}$ volume (i.e., $50 \mathrm{ng}$ of template DNA, 10 pmol of each primer, $0.25 \mathrm{U}$ of Taq DNA polymerase, $250 \mu \mathrm{M}$ of dNTPs mix, $10 \mu \mathrm{M}$ of Tris- $\mathrm{HCl}(\mathrm{pH} 9.0), 30 \mu \mathrm{M}$ of $\mathrm{KCl}, 1.5 \mu \mathrm{M}$ of $\mathrm{MgCl} 2$, and sterile nuclease-free water). PCR amplification was conducted in a thermocycler (Labnet International Inc.). The following cycling conditions were used: pre-denaturation at $94{ }^{\circ} \mathrm{C}$ for 5 minutes, denaturing at $94{ }^{\circ} \mathrm{C}$ for 30 seconds, annealing at 58 ${ }^{\circ} \mathrm{C}$ for 30 seconds, extension at $72{ }^{\circ} \mathrm{C}$ for 30 seconds for 35 cycles, and a final extension at 72 ${ }^{\circ} \mathrm{C}$ for 10 minutes. In addition, we used glyceraldehyde-3-phosphate dehydrogenase $(\mathrm{GAPDH})$ as a reference gene. The amplified fragments were analyzed by gel electrophoresis using a DNA ladder in order to assess the size of the amplicons products. The images were obtained using a gel documentation system (Ultra-Violet Products Ltd.). The 
size of the amplicons was determined using software available with the gel documentation system.

\section{Cloning}

The obtained PCR products were cloned using GenScript's CloneEZ PCR cloning kit (www.genscript.com). After that, the amplified gene was sequencing at (Bioneer Inc, Daejeon, Republic of Korea). The sequencing alignment was done using nucleotidenucleotide BLAST (BLASTN) software in http://www.ncbi.nlm.nih.gov/blast/ and CLASTALW 2.0.12 to compare the similarities with related avian species. The phylogenetic tree was constructed using MEGA version 6.1 software (Tamura and Nei 1993; Tamura et al. 2013).

\section{Sequence analyses}

The order/disorder propensities of the $\beta$-defensins- 9 from the local chicken (identical to $\beta$ defensin-9 or gallinacin-9 from Gallus gallus, UniProt ID: Q6QLR1), duck (Anas platyrhynchos, UniProt ID: A3FPG7), quail (Coturnix coturnix, UniProt ID: D0F1S0), goose (Anser cygnoid, UniProt ID: G0Z9C4), rat (Rattus norvegicus, UniProt ID: Q32ZI2), mouse (Mus musculus, UniProt ID: Q8R2I6), cow (Bos taurus, UniProt ID: P46167), and buffalo (Bubalus bubalis, UniProt ID: A3RJ39) were evaluated using the PONDR $^{\circledR}$ (Predictor $\underline{\text { Of }}$ Natural Disordered Regions) VSL2 algorithm (Peng et al. 2005), which is one of the more accurate stand-alone disorder predictors (Fan and Kurgan 2014; Peng et al. 2005; Peng and Kurgan 2012). The outputs of the evaluation of disorder propensity are represented by the real numbers between 1 (ideal prediction of disorder) and 0 (ideal prediction of order). An arbitrary threshold of $\geq 0.5$ was used to identify disorder. 
In addition to the per-residue disorder distribution in proteins, their overall disorder status was evaluated by the so-called binary disorder classifier, the charge-hydropathy $(\mathrm{CH})$ plot (Oldfield et al. 2005; Uversky et al. 2000), which is the computational tool that evaluate the predisposition of a given protein to be ordered or disordered as a whole. In this approach, the absolute mean charge $<\mathrm{R}>$ for each of the $\beta$-defensin- 9 proteins was calculated as the absolute value of the difference between the numbers of positively charged and negatively charged amino acid residues divided by the total number of amino acids. The hydrophathy of each amino acid residue was computed by the Kyte and Doolittle approximation (Kyte and Doolittle 1982) with a window size of 5 and normalization on the scale from 0 to 1 . The mean normalized hydrophathy $<\mathrm{H}>$ was defined as the sum of the normalized hydrophobicities of all residues divided by the total number of residues minus 4 (Oldfield et al. 2005; Uversky et al. 2000). The results were presented in a charge-hydropathy plot.

\section{Real time PCR}

The constitutive expression patterns of $\beta$-defensin-9 in different tissues of local Saudi chicken were performed through the real-time RT-PCR method using SYBR Green qPCR Master mix containing ROX as a reference dye (Biotool LLC, Houston, USA). Total RNAs were isolated from different tissues, then RT was conducted using oligo-dT primers (Bioneer Inc, Daejeon, Republic of Korea) in a $20 \mu \mathrm{L}$ reaction including $5 \mu \mathrm{L}$ RNA. The real time PCR was achieved with (Stratagene Mx3005P QPCR Systems, Agilent Technologies, Germany), the cycling conditions used as follows: activation at $95^{\circ} \mathrm{C}$ for 10 minutes, denaturing at $95^{\circ} \mathrm{C}$ for 15 seconds, annealing/extension at $58^{\circ} \mathrm{C}$ for 30 seconds for 40 cycles. The melting was conducted from 95 to $60^{\circ} \mathrm{C}$ with read every $0.2^{\circ} \mathrm{C}$ and $5 \mathrm{~s}$ hold between reads. All amplified fragments were achieved in three independent replicates; in addition, the results were 
normalized to glyceraldehyde-3-phosphate dehydrogenase (GAPDH) as a reference gene using comparative $\mathrm{C}_{\mathrm{t}}$ method.

\section{Bacterial species}

Bacterial species used in the biocidal analysis included both Gram-negative and Grampositive strains. The five Gram-positive bacterial strains used were: Methicillin-Resistance Staphylococcus aureus ATCC 43330 (MRSA), Staphylococcus epidermidis ATCC 12228 (S. epidermidis), Enterococcus faecalis ATCC 29212 (E. faecalis), Streptococcus bovis ATCC 49147 (S. bovis), and Micrococcus luteus ATCC 49732 (M. Luteus). Five strains of Gramnegative bacteria involved: Shigella sonnei ATCC 25931 (S. sonnei), Pseudomonas aeruginosa ATCC 27853 (P. aeruginosa), Salmonella typhimurium ATCC 14028 (S. typhimurium), Klebsiella pneumonia ATCC 700603 (K. pneumonia), and Escherichia coli ATCC 25922 (E. coli). The bacterial strains were cultured on tryptone soy agar and incubated for $24 \mathrm{~h}$ at $37^{\circ} \mathrm{C}$ and stored in slants at $4^{\circ} \mathrm{C}$.

\section{Fungal species}

As in previous study, three fungal species were used; Candida albicans ATCC 10231 (C. albicans), Aspergillus flavus (A. flavus) and Aspergillus niger (A. niger) isolates (obtained from the Department of Biological Sciences, King Abdulaziz University, Jeddah, Saudi Arabia. Filamentous fungi and Candida were cultured in Sabouraud dextrose agar and incubated at $25-28{ }^{\circ} \mathrm{C}$ for $72 \mathrm{~h}$ for multicellular fungi and h at $30^{\circ} \mathrm{C}$ for 24 in the case of Candida and stored in slants at $4{ }^{\circ} \mathrm{C}$. 


\section{Chicken $\beta$-defensin peptide synthesis}

The full amino acid sequence of chicken $\beta$-defensin-9 peptide was synthesized and purified to $80 \%$ level using high-performance liquid chromatography (HPLC) by GL Biochem Ltd. (Shanghai, China) (http://www.glschina.com/en/profile) (Table 1). The peptide was checked for endotoxin content according to (Redwan 2012).

\section{Antimicrobial activity assay}

Minimal inhibitory concentration (MIC) assays for the peptide were performed by the broth dilution method with Mueller Hinton II broth according to the procedures suggested by the CLSI (Clinical and Laboratory Standards Institute) (CLSI 2009, 2012). In summary, as in previous study, bacteria and candida were grown to reach the exponential phase, which took around three hours. Cells were then centrifuged at $2000 \times \mathrm{g}$ for $15 \mathrm{~min}$. The resulting pellets were washed and resuspended in $10 \mathrm{mM}$ PBS (pH 7.0). Two-fold serial dilutions of the sAvBD-9 were prepared in appropriate culture medium in 96-microwell plates. Inoculum $(100 \mu \mathrm{L})$ from the culture with a bacterial density of $106 \mathrm{CFU} / \mathrm{ml}$ was added to each individual well containing $100 \mu \mathrm{L}$ of either $\mathrm{M}-\mathrm{H}$ alone, or $\mathrm{M}-\mathrm{H}$ containing two fold diluted peptide to give a final concentration of the peptide ranging from 0-200 $\mu \mathrm{M}$. Tetracycline was used for bacteria, while and Ketoconazole was used in the case of both yeasts and fungi as a reference. The MIC values were recorded as the minimum concentration that showed no visible growth after overnight incubation at $37^{\circ} \mathrm{C}$.

The minimum inhibitory concentration for the bacteria (MBC) or minimum inhibitory fungicidal concentration (MFC) values were determined by sub-culturing $10 \mu \mathrm{L}$ from each MIC positive well onto minimal $\mathrm{M}-\mathrm{H}$ agar. The lowest peptide concentration yielding more than $99 \%$ of either bacterial or fungal growth inhibition was noted as the MBC or MFC, 
respectively. In case of multicellular fungi $A$. niger and $A$. flavus which used to evaluate the anti-fungal activity of $\beta$-defensin-9, overnight cultures of the fungi were prepared by inoculating $100 \mathrm{ml}$ of Sabouraud dextrose broth with a 105 spores/ml concentration.

\section{Kinetics of the microbe inactivation by sAvBd-9}

Three organisms, MRSA, and E. coli $(1 \times 108 \mathrm{CFU} / \mathrm{ml})$ and C. albicans $(1 \times 105 \mathrm{CFU} / \mathrm{ml})$, were used to study the killing kinetics of sAvBD-9. The sAvBD-9 concentration used in these experiments was 2 times of that of the MIC. Overnight bacterial cultures were prepared. The cultures were spun down and resuspended in fresh Müller-Hinton agar (MH medium) at a concentration of $1 \times 106 \mathrm{CFU} / \mathrm{ml}$. sAvBD-9 was then added to the bacterial suspension, at a concentration equivalent to 2 times that of the MIC. The mixture was incubated at $37^{\circ} \mathrm{C}$. The colony forming units (CFUs) were determined at 0, 15, 60, 120 and $180 \mathrm{~min}$ (Ma et al. 2011). At each time point, $1 \mu \mathrm{L}$ of the suspension was inoculated into $1 \mathrm{ml}$ of MH medium. Diluted bacterial suspension $(50 \mu \mathrm{L})$ was plated out and incubated at $37^{\circ} \mathrm{C}$ for $12 \mathrm{~h}$ before counting.

\section{Effect of ionic stress on the peptide antimicrobial activity}

In order to evaluate the effects of $\mathrm{NaCl}$ concentrations on the antibacterial activity of sAvBd9, E. coli was used. The tested bacteria was subcultured at $37^{\circ} \mathrm{C}$ to the mid-log phase, and suspended to $106 \mathrm{CFU} / \mathrm{ml}$ in $\mathrm{MH}$ medium. A suspension of E. coli $(1 \mathrm{ml})$ was incubated with the different concentrations of peptide $(0-200 \mu \mathrm{g} / \mathrm{mL})$ and the different $\mathrm{NaCl}$ concentrations $(0,20,50,150 \mathrm{mM})$ in $10 \mathrm{mM}$ sodium phosphate buffer, $\mathrm{pH} 7.4$. The tested bacteria were cultured at $37^{\circ} \mathrm{C}$ for $2 \mathrm{~h}$ before diluting 1000 times followed by plating. Survived bacteria were counted (Baricelli et al. 2015; Ma et al. 2011; Wang et al. 2011; Yacoub et al. 2015). 


\section{Hemolysis test}

The hemolytic activity of the synthetic defensin was measured according to (Ma et al. 2013; Shin et al. 2001; Yacoub et al. 2015; Yu et al. 2001). Briefly, fresh chicken blood was collected from King Abdulaziz University farm, Jeddah, KSA. The blood was spun down for erythrocytes harvesting by centrifugation $\left(3000 \mathrm{rpm}, 10 \mathrm{~min}\right.$, at $\left.20^{\circ} \mathrm{C}\right)$. The resulting erythrocytes were then washed twice with sterile PBS at a concentration of $0.5 \% \mathrm{vol} / \mathrm{vol}$ and were used for the assay, by dispensing $90 \mu \mathrm{L}$ into each well of the 96-well plates. Then, 10 $\mu \mathrm{L}$ of solution containing different peptide concentrations were added to the cells and incubated at $37^{\circ} \mathrm{C}$ for $2 \mathrm{~h}$. After incubation, the microtiter was spun down at $800 \times \mathrm{g}$ for 10 min. The supernatants were withdrawn and transferred to a new 96-well plate and checked for released hemoglobin as measured spectrophotometerically at $405 \mathrm{~nm}$. For (0 hemolysis) as well as (100\% hemolysis) controls, cells were resuspended in PBS only and in 1\% Triton X100 , respectively.

\section{Morphology of the sAvBd-9 nanoparticles}

For the transmission electron microscopy (TEM) assay, the $\beta$-defensin-9 nanoparticles were suspended in $(0.01 \%)$ acetic acid, then treated in an ultrasonic bath (BRANSON, 1510) for 30 min. A small drop of this suspension was placed on carbon-coated copper grid which was dried at room temperature. The specimens were examined with a transmission electron microscope JEM-1011 (JEOL, Tokyo, Japan).

\section{Effects of chicken $\beta$-defensin-9 on the bacterial morphology}

Cultures of $S$. aureus, MRSA ATCC (43330) and S. sonnei ATCC (25931) were grown in MH broth to early exponential phase then harvested by centrifugation. The bacterial pellets 
were washed in PBS and resuspended to an OD600 of 0.2. The cell suspension was treated with $\beta$-defensin-9 (at $2.5 \times$ and $5 \times \mathrm{MIC}$ ). After one-hour of incubation, the cells were centrifuged and washed with PBS, then fixed with $2.5 \%$ glutaraldehyde. After fixation, the sample were dropped on carbon coated copper grid and waiting until dry. The grid then was stained with the Phosphotingestic Acid (PTA) stain. Finally, the grid was dried at room temperature and become ready to examine with the transmission electron microscopy (TEM).

\section{Statistical analysis}

Data were entered using IBM SPSS Statistics 20, and was analyzed by Kaplan-Meier analysis. A P level of $<0.05$ was considered to be significant.

\section{Results}

In this study, the transcriptional profile of $\beta$-defensin-9 in local chicken from Saudi Arabia and the antimicrobial activity of the synthetic $\beta$-defensin-derived peptide-9 (sAvBD-9) against the most frequent human pathogens were characterized. Furthermore, to investigate the effect of this peptide on the morphology of bacterial cells, the electron transmission microscopy (TEM) was used.

\section{Identification and phylogenetic analysis of $\beta$-defensin-9}

We were able to amplify a DNA fragment of $204 \mathrm{bp}$ that corresponded to a complete nucleotide sequence of the cDNA of $\beta$-defensin-9 in local chicken from Saudi Arabia. The amplified fragment was sequenced and deposited in GenBank (accession number, KR136304). The analysis of sequence alignments was used to find the similarities of this $\beta$ - 
defensin-9 from local Saudi chicken with the nucleotide sequences of related avian species using nucleotide-nucleotide BLAST (http:/www.ncbi.nlm.nih.gov/blast) and CLASTALW 2.12 software. This analysis revealed that the nucleotide sequence of a newly identified $\beta$ defensin- 9 has a high similarity $(99 \%, 97 \%$ and $91 \%)$ with the $\beta$-defensin- 9 sequences of duck, quail, and goose, respectively (Figure 1). Next, the phylogenetic tree was constructed based on the nucleotide sequences of the $\beta$-defensin- 9 from the local Saudi chicken, the other related avian species, and some mammalian $\beta$-defensins-9.

This analysis revealed that the local chicken $\beta$-defensin- 9 is closely related to the $\beta$ defensins-9 from Gallus gallus and duck, with all three sequences being clustered in same group as shown in Figure 2. However, $\beta$-defensins-9 of two other avian species, quail and goose, were grouped together in a single sub-cluster. The same trend observed in case of mammalian defensins (Figure 2). The multiple polypeptide sequence alignment of the complete amino acid sequence of the $\beta$-defensin- 9 from the local chicken revealed a highly similarity with $\beta$-defensins- 9 from duck, quail, and goose $(97 \%, 87 \%$, and $86 \%$, respectively) (see Figure 3).

\section{Intrinsic disorder propensity of $\beta$-defensins}

The intrinsic disorder propensities of avian and mammalian $\beta$-defensins- 9 were evaluated by PONDR $^{\circledR}$ VSL2 (Peng et al. 2005) (see Figure 4A). Here, the scores above 0.5 are considered to correspond to the disordered residues/regions. This analysis revealed that $\beta$-defensins- 9 are expected to be rather ordered, a conclusion illustrated by Figure 4A representing the aligned PONDR $^{\circledR}$ VSL2-based disorder profiles for various $\beta$-defensins-9. It is also seen that although these proteins are predicted to be mostly disordered, some of them possess disordered or flexible regions. Figure 4A also illustrates that based on the peculiarities of 
their per-residue disorder propensities, $\beta$-defensins- 9 analyzed in this study can be grouped into three sets. Here, $\beta$-defensins-9 from chicken, duck, quail, and goose have rather similar disorder profiles and form one group, $\beta$-defensins-9 from rat and mouse are also characterized by comparable disorder profiles and form another group, with the third group being formed by $\beta$-defensins-9 from cow and buffalo. Close similarities of disorder profiles within these groups suggest that the group-conserved disorder-related sequence features can have functional implications. The most ordered N-terminal parts of the avian $\beta$-defensins-9 and defensins from mouse and rat correspond to the signal peptide (residues 1-19).

One of alternative approaches for the evaluation of the disorder propensity of a protein is based on classifying an entire protein as mostly ordered or disordered based only two parameters of a particular amino acid sequence - absolute mean net charge and mean hydrophobicity (Oldfield et al. 2005; Uversky et al. 2000). The resulting plot of the absolute mean net charges of proteins $<\mathrm{R}>$ against their mean hydropathy $<\mathrm{H}>$ represents a chargehydropathy plot (CH-plot) which shows that ordered and disordered proteins tend to occupy two different areas within the charge-hydrophobicity phase space, separated by an estimated boundary line, $<\mathrm{R}>=2.785<\mathrm{H}>-1.151$ (Uversky et al. 2000). It was also pointed out that the $\mathrm{CH}$-plot is able to discriminate proteins with substantial amounts of extended disorder (random coils and pre-molten globules, which are located above the boundary) from proteins with globular conformations (molten globule-like and ordered globular proteins, which are positioned below the boundary) based on charge and hydropathy of their sequences (Oldfield et al. 2005). Figure 4B shows that all $\beta$-defensins-9 are located below the boundary separating compact proteins and extended disordered proteins and are, therefore, predicted to have compact structures. In addition, all the $\beta$-defensins-9 are positioned deep within the area corresponding to compact/ordered proteins and is characterized by high mean hydropathy. Furthermore, Figure 4B shows that the hydropathy is unequally distributed within the $\beta$ - 
defensin-9 sequence, with the N-terminally located signal peptide being the most hydrophobic part of this protein.

\section{Tissue distribution and expression of $\beta$-defensin-9}

To characterize the expression patterns of $\beta$-defensin- 9 within the local chicken, a wide range of its tissues were collected. The real time RT-PCR was used to determine the expression levels of $\beta$ defensin-9 in local chicken (Figure 5). In our study, we used the baseline 1 or -1 , therefore the range of changes in the expression level was defined to be between $+X$ and +1 when the gene was upregulated and between $-X$ and -1 when it was down-regulated. Figure 5 shows that the $\beta$-defensin-9 gene is highly expressed in sexual organs, especially in testis and ovum. Furthermore, the $\beta$ defensin-9 transcripts were found in the gastrointestinal tract. The highest levels of $\beta$-defensin-9 expression were found in several tissues, such as liver, large intestine, muscle, and gizzard, whereas a moderate expression was recorded in stomach, ovum, duodenum, lungs, uterus, testis and kidney. Finally, no expression $\beta$-defensin-9 was found in spleen, oviduct, bone marrow, skin and heart.

\section{The antimicrobial activity of SAvBD-9}

A significant antimicrobial activity of the synthetic $\beta$-defensin-derived peptide (sAvBD-9) was observed against all bacterial pathogens tested in this study (Table 2). This analysis revealed that the sAvBD-9 had an ability to inhibit both Gram-negative and Gram-positive bacteria, being present in the medium at low concentrations. Specifically, the efficiency of sAvBD-9 against S. sonnei was characterized by the MIC of $3.2 \mu \mathrm{g} / \mathrm{ml}$ and the MBC of 6.25 $\mu \mathrm{g} / \mathrm{ml}$, whereas for K. pneumonia, E. faecalis, and S. aureus (MRSA) the MIC and MBC were of $6.25 \mu \mathrm{g} / \mathrm{ml}$ and $6.25 \mu \mathrm{g} / \mathrm{ml}$, respectively. 
Furthermore, it is worthy to mention that sAvBD-9 exerted effective toxicity against the three fungal species analyzed in this study (Table 2), A. flavus (MIC $3.2 \mu \mathrm{g} / \mathrm{ml}$ and MFC 3.2 $\mu \mathrm{g} / \mathrm{ml}$ ) than A. niger (MIC $3.2 \mu \mathrm{g} / \mathrm{ml}$ and MFC $6.25 \mu \mathrm{g} / \mathrm{ml}$ ) and C. albicans at (MIC 6.25 $\mu \mathrm{g} / \mathrm{ml}$ and MFC $6.25 \mu \mathrm{g} / \mathrm{ml})$.

\section{Kinetic characterization of the SAvBD-9 biocidal activity}

The kinetics of the sAvBD-9 killing efficacy was determined for the representative organisms from both Gram-positive and Gram-negative bacterial strains, as well as the fungal C. albicans strain (Figure 6). These analyses revealed that the sAvBD-9, being present at the concentration of $25 \mu \mathrm{g} / \mathrm{L}$, was a fast and efficient killer of fungi, Gram-negative and Grampositive bacteria, reducing cell survival within the first hour to below the detection limit of 100 cells $/ \mathrm{ml}$. At the second hour, the peptide exhibited higher antimicrobial efficacy against of MRSA strain than against other tested organisms $(P<0.001)$. Finally, sAvBD-9 was more effective in reduction of the survival levels of the Gram-positive bacteria than of the Gramnegative bacteria and fungi.

\section{Effect of ionic stress on the sAvBD-9 antimicrobial activity}

The antibacterial effect of the sAvBD-9 against tested bacteria was evaluated in the presence of $0,12.5,25,50,100$, and $150 \mathrm{mM} \mathrm{NaCl}$ at different concentrations of tested peptide $(0,12.5,25,50,100,150$, and $200 \mu \mathrm{g} / \mathrm{mL})$ as depicted in (Figure 7). This analysis revealed that the SAvBD-9 had similar bactericidal effect against tested bacteria at concentrations ranged from 0 to $50 \mathrm{mM} \mathrm{NaCl}$. In contrast, the antimicrobial activity of this synthetic peptide was significantly reduced in the presence of 100 and $150 \mathrm{mM}$ of $\mathrm{NaCl}(P<$ $0.001)$. 


\section{The haemolytic activity of sAvBD-9}

The haemolytic activity of the synthetic peptide was evaluated using the freshly isolated chicken erythrocytes that were incubated with the sAvBD-9 peptide. The hemolysis was observed by measuring the absorbance of the released hemoglobin at $400 \mathrm{~nm}$ as noticed in Figure 8. The sAvBD-9 peptide displayed a limited haemolytic effect against chicken erythrocytes at different peptide concentrations.

\section{Effect of chicken $\beta$-defensin-9 on bacterial cell morphology}

Figure 9 shows that according to the TEM analysis, the size of the avian $\beta$-defensin- 9 peptide particles does not exceed $10 \mathrm{~nm}$ as pointed by arrows. Then we monitored the ultrastructural changes of S.aureus (MRSA) and S. sonnei cells upon exposure to $\beta$-defensin9 at $2.5 \times$ and $5 \times$ MIC. Untreated individual S.aureus and S. sonnei cells appeared spherical and rod shaped with smooth and intact cell membranes, and no cell damage was obvious in the control samples (see Figures 10a, 11a). The abilities of the synthetic peptide to induce damage of the bacterial cell membrane and to promote cell lysis were observed through the TEM analysis (Figures 10 and 11). At the concentration of $2.5 \times \mathrm{MIC}$, the defensin was able to induce significant deterioration of the microbial cell membrane ultrastructure (Figures 10b and $11 \mathrm{~b}$ ). The increase of the SAvBD-9 concentration to $5 \times$ MIC promoted extensive damage to the cell wall, loss of cell walls, decrease in the cell volume, and other alterations in the cellular morphology (Figures 10c and 11c). At concentrations of $5 \times \mathrm{MIC}$, the evanescence of cytoplasm constituents was very clear for both Gram-positive and Gram-negative bacteria. 


\section{Discussion}

The excessive and uncontrolled use of antibiotics in the treatment of infectious disease has resulted in the emergence of highly multi-drug resistant bacteria insensitive to antibiotics, thus creating a major problem to the public health at large. For this reason, finding suitable alternatives to antibiotics has been sought for a long time.

One of the possible natural substitutions includes the use of the host defense peptides (HDPs) that have a fundamental role in the innate immunity in several vertebrates and invertebrates. They have also shown to have immunomodulatory functions. One thousands of HDPs have been discovered so far. Three of those HDPs are related to chickens, $\beta$-defensins, cathelicidens, and liver antimicrobial peptide- 2 .

We conducted this study to identify the transcriptional profile of the $\beta$-defensin- 9 in local chicken from Saudi Arabia, to determine the antimicrobial activities of the derived synthetic (sAvBD-9) peptide against pathogenic bacteria and fungi, and to investigate the mode of action of sAvBD-9 on bacterial cells using transmission electron microscopy.

We report here the results of the transcriptional profiling of the $\beta$-defensin- 9 in local chicken from Saudi Arabia. The results of the multiple nucleotide sequence alignments using BLAST (http://www.ncbi.nlm.nih.gov/blast) and CLASTALW 2.12 indicated that the $\beta$ defensin-9 sequence of the local chicken is highly homologous to other avian defensins, such as duck, quail, and goose. At the protein level, the $\beta$-defensin-9 polypetide from the local chicken is identical to the duck $\beta$-defensin-9 and has high similarity to the quail peptide followed by the goose counterpart. These findings are in agreement with the results of earlier studies on duck, goose, and quail $\beta$-defensins-9 (Lu et al. 2014; Ma et al. 2012a; Ma et al. 2011; Ma et al. 2008; Ma et al. 2012b; Ma et al. 2012c; Zhang and Sunkara 2014). 
Our analysis also revealed that the $\beta$-defensin- 9 from local chicken has four exons region and the corresponding transcipt contains six highly conserved cysteins, starts with the highly hydrophobic signal peptide at N-terminus (residues 1-19) and terminates as a C-terminallylocated mature peptide. This peptide structure could be related to its antimicrobial activity as reported in (Zasloff 2002). The phylogenetic analysis of the local chicken $\beta$-defensin-9 indicated that this peptide is grouped with the duck protein and forms the sub-cluster with quail and goose counterparts. This analysis also demonstrated the presence of very close ancestor and evolutionary relationships between the avian $\beta$-defensins-9. In contrast, this peptide shared a very low homology with mammalian defensins as was previously reported for the most of the avian $\beta$-defensins-9 (Cormican et al. 2008; Cuperus et al. 2013; Lu et al. 2014; Xiao et al. 2004).

Analysis of the intrinsic disorder predisposition of various defensins revealed that although all of them are expected to be mostly ordered, the disorder propensity and the sequence charge/hydropathy are unequally distributed within the $\beta$-defensin- 9 sequence, with the Nterminally located signal peptide being the most ordered and highly hydrophobic part of this protein.

The high overall hydropathy of the full-length avian $\beta$-defensins- 9 is expected to make them insoluble. It is also expected that the unequal distribution of the disorder propensity, hydropathy, and charge within these proteins would force them to form micelle-like structures, with the N-terminal signal peptides being located within the core of the resulting particles, and with the less hydrophobic and more charged/polar C-terminal regions being solvent-exposed and located on the surface of these particles.

Analysis of the tissue distribution of the $\beta$-defensin- 9 of local chicken revealed that peptide was expressed in different organs and tissues, and these results were comparable with the 
results of earlier studies (Higgs et al. 2005; Lynn et al. 2004; Ma et al. 2008; van Dijk et al. 2007; Zhao et al. 2001). The strong expression the $\beta$-defensin-9 was found in liver, large intestine, muscle, gizzard, pancreas, and kidney (Lynn et al. 2004; van Dijk et al. 2007; Xiao et al. 2004). Female and male reproductive tracts were characterized by a moderate expression of this protein, whereas the lymphoid organs possessed low to moderate levels of the $\beta$-defensin-9 (Cuperus et al. 2013; Lynn et al. 2004; van Dijk et al. 2007; Xiao et al. 2004; Zhao et al. 2001). Such tissue/organ distribution of defensins has biological meaning since it is well-known that these antimicrobial peptides might be expressed constitutively or be inducible as a response to the invading pathogen, and the site of their production is controlled by their secretions (Ma et al. 2011; Michailidis et al. 2012; Milona et al. 2007; Zhao et al. 2001).

We also revealed that the synthetic avian the $\beta$-defensin-9 (sAvBD-9) displayed broadspectrum antimicrobial activities against both Gram-positive and Gram-negative strains in comparison with the conventional antibiotics. Our results are consistent with other reports in respect with the antimicrobial activity of various avian $\beta$-defensins (Evans et al. 1995; Evans et al. 1994; Harwig et al. 1994; Higgs et al. 2005; Lynn et al. 2004; Ma et al. 2012a; Ma et al. 2011; Ma et al. 2012b; Ma et al. 2012c; Soman et al. 2010; Thouzeau et al. 2003; van Dijk et al. 2008; Wang et al. 2010; Zhang et al. 2011; Zhang et al. 2012). For example, the $\beta$ defensins-2 and 7 from ostrich were shown to exhibit strong antibacterial activities against both Gram-positive and Gram-negative bacteria (Lu et al. 2014).

Similarly, the duck-derived recombinant $\beta$-defensin-2 showed a potent bactericidal potential against $P$. multocid and $S$. aureus. However, this peptide exhibited weak potential against $S$. choleraesuis and E. coli, and similar trends were reported for other defensins, which were either chemically synthesized or produced recombinantly (Evans et al. 1994; 
Harwig et al. 1994; Higgs et al. 2005; Ma et al. 2008; Milona et al. 2007; Sugiarto and Yu 2004; Thouzeau et al. 2003; van Dijk et al. 2007; Yu et al. 2001).

Interestingly, besides its antibacterial effects, the sAvBD-9 analyzed in our study exhibited a prominent fungicidal activity against both unicellular and multicellular fungi. The high levels of the fungicidal activity reported in our study are comparable with the previous reports showing that the sAvBD-4 and 10 had significant anti-fungal potentials against several fungi species. However, the sAvBD-9 fungicidal effects have not been studied before. Overall, our results of the analysis of the biocidal potential of the sAvBD are consistent with the earlier reports which demonstrated that the defensin-like proteins where able to display a strong inhibitory potential against human and plant infectious agents (Lacadena et al. 1995; Marx 2004; Meyer 2008; Meyer and Stahl 2002).

The kinetic analysis of the killing potential of the sAvBD-9 peptide against MRSA, E. coli and $C$. albicans revealed that this defensins was noticeably more efficient against MRSA than against two other pathogens, E. coli and C. albicans. The sAvBD-9 activity was confirmed to be lethal for MRSA, which could not be revived after the 3-hour-exposure to the peptide, suggesting its sufficient antibacterial potency. The variations in the kinetics describing the peptide antibacterial activity may be determined by its high cationicity (pI 9.75) and distinguished hydrophobicity $(0.38)$, as well as by the types of bacteria used. The aforementioned intrinsic structural characteristics of the $\beta$-defensin- 9 , such as high hydrophobicity, high cationicity, high pI values ( $>9)$, and noticeable helical propensity are known to be important determinants of the antimicrobial potency of protein and peptides (Redwan et al. 2014). Similar data were reported for pheasant cathelicidin-1 (Pc-CATH1) that inhibited $E$. coli growth at the first hour and the bacterial growth was not resumed after 6 hours (Wang et al. 2011). 
Although the sAvBD-9 was resistant to salt up to $50 \mathrm{mM} \mathrm{NaCl}$, it lost its bactericidal and fungicidal potentials in the presence of higher $\mathrm{NaCl}$ concentrations. These effects of salinity on the sAvBD-9 activity are in agreement with other reports on most tested defensins and other antimicrobial peptides (Bals et al. 1998; Porter et al. 1997; Veldhuizen et al. 2008; Zucht et al. 1998). Results reported earlier for three goose defensins revealed that their antimicrobial activity against both Gram-negative and Gram-positive bacteria was efficiently inhibited by sodium chloride (Ma et al. 2011).

Furthermore, beside the significant antimicrobial potential of sAvBD-9, this peptide displayed low haemolytic activity and low toxicity against animal cells. These findings are in agreement with the results of earlier investigations of other avian $\beta$-defensins and their mammals counterparts (Ma et al. 2011; Ma et al. 2012b; Ma et al. 2012c; Milona et al. 2007; Veldhuizen et al. 2008). In fact, other reports indicated that the avian defensins and their derivatives/counterparts typically possessed low cytotoxic activity toward the animal cells. This potentiality was attributed to the higher levels of cholesterol in the membranes of these cells and to the lack of negatively charged molecules incorporated into the phospholipid bilayer of animal membranes (Ishitsuka et al. 2006; Lu et al. 2014; Ma et al. 2013; Matsuzaki et al. 1995).

Nowadays, the bioactive peptides that are derived from the natural compound have received essential attention especially in their relation to the public health, due to the safety and low level of side effects of these natural biocides. Several reports indicated that the electron microscopy can provide some relevant information on the peptide-induced damage in the bacterial cell membranes (Cellini et al. 2008; Hillier and Baker 1946, 1947; Mcfarlane 1949). The modes of the antibacterial action of such biocidal peptides are based on the type of the bacterial organisms, being especially sensitive to the structure of the cell wall and the outer membrane arrangement. Some peptides may be able to penetrate the bacterial cell 
membrane and successfully led to the release of the cytoplasmic contents into the surrounding environment. We observed this mode of the sAvBD-9 action for both Gram-positive and Gram-negative bacteria.

The fact that sAvBD-9 and other synthetic or recombinant defensins have strong biological activity in the aggregated state is of special importance. In fact, in the protein literature, there is a strong believe that the non-specific protein or peptide aggregation are processes with strong negative connotation typically related to dysfunction. Data reported in our work and in earlier studies suggest that such non-specific aggregation of defensins might be beneficial. Díaz-Visurraga et al. reported that the nanoparticles are expected to generate higher local concentrations of charged particles at the bacterial membrane, thus enhancing the antimicrobial activity (Díaz-Visurraga et al. 2010).

\section{Conclusions}

In local chicken from Saudi Arabia, the coding region of $\beta$-defensin-9 contained $204 \mathrm{bp}$ and encoded a 67 amino acid-long polypeptide. The amino acid sequence of this $\beta$-defensin-9 possessed a highly similarity to the analogous peptides from duck, quail, and goose $(97 \%$, $86 \%$, and $87 \%$, respectively). In contrast, this peptide shared a low homology with mammalian defensins. Our analysis revealed that the $\beta$-defensin- 9 was expressed in various organ and tissues of local chicken. The antimicrobial activity of synthetic chicken $\beta$-defensin9 was studied against a wide set of infectious pathogens, including bacterial and fungal species. This peptide exhibited high antimicrobial activities against a broad spectrum of Gram-positive and Gram-negative bacteria representing concern to the public health. Interestingly, besides its broad spectrum of antibacterial activities, synthetic AvBD-9 has shown profound fungicidal potential against C. albicans, A. flavus, and A. niger. The analysis 
revealed that the synthetic AvBD-9 was very efficacious anti-fungal agents causing more than $98 \%$ reduction in the fungi survival as compared to the control. The peptide was resistant to salt concentrations up to $50 \mathrm{mM} \mathrm{NaCl}$, but lost its antimicrobial potential in a milieu containing higher salt concentrations (100 mM and $150 \mathrm{mM} \mathrm{NaCl})$. This peptide displayed low haemolytic effects. Overall, our analyses showed that the synthetic avian $\beta$ defensin-9 has a potent antimicrobial activity against a broad spectrum of pathogens. Therefore, such peptides should be analyzed in more detail for their full potentials of the disease treatment in both humans and animals. It is likely that these bioactive peptides represent a possible alternative to antibiotics and can serve as natural antimicrobial agents. The hope also is that due to their naturally occurrence and natural properties, these peptides would not provoke bacterial resistance.

\section{Acknowledgements}

The authors thank the Deanship of Scientific Research (DSR, King Abdulaziz University, Jeddah) for the technical and financial support. This work was funded by the Deanship of Scientific Research (DSR, King Abdulaziz University, Jeddah) under grant no. 273-1301433. The authors are solely responsible for the contents of this paper. 


\section{References}

Achanta, M., Sunkara, L.T., Dai, G., Bommineni, Y.R., Jiang, W., and Zhang, G. 2012. Tissue expression and developmental regulation of chicken cathelicidin antimicrobial peptides. Journal of animal science and biotechnology 3(1): 15. doi: 10.1186/2049-1891-3-15.

Bals, R., Wang, X.R., Wu, Z.R., Freeman, T., Bafna, V., Zasloff, M., and Wilson, J.M. 1998. Human beta-defensin 2 is a salt-sensitive peptide antibiotic expressed in human lung. Journal of Clinical Investigation 102(5): 874-880. doi: 10.1172/Jci2410.

Baricelli, J., Rocafull, M.A., Vazquez, D., Bastidas, B., Baez-Ramirez, E., and Thomas, L.E. 2015. beta-defensin-2 in breast milk displays a broad antimicrobial activity against pathogenic bacteria. Jornal De Pediatria 91(1): 36-43. doi: 10.1016/j.jped.2014.05.006.

Brogden, K.A. 2005. Antimicrobial peptides: Pore formers or metabolic inhibitors in bacteria? Nature Reviews Microbiology 3(3): 238-250. doi: 10.1038/Nrmicro1098.

Cellini, L., Grande, R., Di Campli, E., Di Bartolomeo, S., Di Giulio, M., Traini, T., and Trubiani, O. 2008. Characterization of an Helicobacter pylori environmental strain. Journal of Applied Microbiology 105(3): 761-769. doi: 10.1111/j.1365-2672.2008.03808.x.

CLSI. 2009. Methods for dilution antimicrobial susceptibility tests for bacteria that grow aerobically; approved standard: Eighth edition. Clinical and Laboratory Standards Institute.

CLSI. 2012. Performance standards for antimicrobial susceptibility testing: 22nd informational supplement. . Clinical and Laboratory Standards Institute.

Cormican, P., Meade, K.G., Cahalane, S., Narciandi, F., Chapwanya, A., Lloyd, A.T., and O'Farrelly, C. 2008. Evolution, expression and effectiveness in a cluster of novel bovine betadefensins. Immunogenetics 60(3-4): 147-156. doi: 10.1007/s00251-007-0269-8. 
Cuperus, T., Coorens, M., van Dijk, A., and Haagsman, H.P. 2013. Avian host defense peptides. Developmental and Comparative Immunology 41(3): 352-369. doi: 10.1016/j.dci.2013.04.019.

Díaz-Visurraga, J., Cárdenas, J.G., and García, A. 2010. Morphological changes induced in bacteria as evaluated by electron microscopy. . In Microscopy: Science, Technology, Applications and Education. . Edited by A. Méndez-Vilas and J. Diaz. Formatex, Badajoz, Spain pp. 307315.

Evans, E.W., Beach, F.G., Moore, K.M., Jackwood, M.W., Glisson, J.R., and Harmon, B.G. 1995. Antimicrobial activity of chicken and turkey heterophil peptides CHP1, CHP2, THP1, and THP3. Veterinary Microbiology 47(3-4): 295-303. doi: 10.1016/0378-1135(95)00126-3.

Evans, E.W., Beach, G.G., Wunderlich, J., and Harmon, B.G. 1994. Isolation of Antimicrobial Peptides from Avian Heterophils. Journal of Leukocyte Biology 56(5): 661-665.

Evans, E.W., and Harmon, B.G. 1995. A review of antimicrobial peptides: defensins and related cationic peptides. Vet Clin Pathol 24(4): 109-116.

Fan, X., and Kurgan, L. 2014. Accurate prediction of disorder in protein chains with a comprehensive and empirically designed consensus. J Biomol Struct Dyn 32(3): 448-464. doi: 10.1080/07391102.2013.775969.

Ganz, T. 2004. Defensins: antimicrobial peptides of vertebrates. Comptes Rendus Biologies 327(6): 539-549. doi: 10.1016/j.crvi.2003.12.007.

Harwig, S.S.L., Swiderek, K.M., Kokryakov, V.N., Tan, L., Lee, T.D., Panyutich, E.A., Aleshina, G.M., Shamova, O.V., and Lehrer, R.I. 1994. Gallinacins - Cysteine-Rich Antimicrobial Peptides of Chicken Leukocytes. Febs Letters 342(3): 281-285. doi: 10.1016/00145793(94)80517-2. 
Higgs, R., Lynn, D.J., Gaines, S., McMahon, J., Tierney, J., James, T., Lloyd, A.T., Mulcahy, G., and O Farrelly, C. 2005. The synthetic form of a novel chicken beta-defensin identified in silico is predominantly active against intestinal pathogens. Immunogenetics 57(1-2): 90-98. doi: 10.1007/s00251-005-0777-3.

Hillier, J., and Baker, R.F. 1946. The Mounting of Bacteria for Electron Microscope Examination. Journal of Bacteriology 52(4): 411-416.

Hillier, J., and Baker, R.F. 1947. The Mounting of Bacteria for Electron Microscope Examination. Journal of Applied Physics 18(3): 271-271.

Ishitsuka, Y., Pham, D.S., Waring, A.J., Lehrer, R.I., and Lee, K.Y.C. 2006. Insertion selectivity of antimicrobial peptide protegrin-1 into lipid monolayers: Effect of head group electrostatics and tail group packing. Biochimica Et Biophysica Acta-Biomembranes 1758(9): 1450-1460. doi: 10.1016/j.bbamem.2006.08.001.

Klotman, M.E., and Chang, T.L. 2006. Defensins in innate antiviral immunity. Nature Reviews Immunology 6(6): 447-456. doi: 10.1038/Nri1860.

Kyte, J., and Doolittle, R.F. 1982. A simple method for displaying the hydropathic character of a protein. J Mol Biol 157(1): 105-132. doi: 0022-2836(82)90515-0.

Lacadena, J., delPozo, A.M., Gasset, M., Patino, B., CamposOlivas, R., Vazquez, C., MartinezRuiz, A., Mancheno, J.M., Onaderra, M., and Gavilanes, J.G. 1995. Characterization of the antifungal protein secreted by the mould Aspergillus giganteus. Archives of Biochemistry and Biophysics 324(2): 273-281. doi: 10.1006/abbi.1995.0040.

Lehrer, R.I., and Ganz, T. 2002. Defensins of vertebrate animals. Current Opinion in Immunology 14(1): 96-102. doi: 10.1016/S0952-7915(01)00303-X. 
Lu, S., Peng, K.M., Gao, Q.S., Xiang, M., Liu, H.Z., Song, H., Yang, K.L., Huang, H.B., and Xiao, K. 2014. Molecular cloning, characterization and tissue distribution of two ostrich betadefensins: AvBD2 and AvBD7. Gene 552(1): 1-7. doi: 10.1016/j.gene.2014.08.019.

Lynn, D.J., Higgs, R., Gaines, S., Tierney, J., James, T., Lloyd, A.T., Fares, M.A., Mulcahy, G., and O'Farrelly, C. 2004. Bioinformatic discovery and initial characterisation of nine novel antimicrobial peptide genes in the chicken. Immunogenetics 56(3): 170-177. doi: 10.1007/s00251-004-0675-0.

Ma, D., Lin, L., Zhang, K., Han, Z., Shao, Y., Wang, R., and Liu, S. 2012a. Discovery and characterization of Coturnix chinensis avian beta-defensin 10, with broad antibacterial activity. Journal of peptide science : an official publication of the European Peptide Society 18(4): 224-232. doi: 10.1002/psc.1437.

Ma, D.Y., Lin, L.J., Zhang, K.X., Han, Z.X., Shao, Y.H., Liu, X.L., and Liu, S.W. 2011. Three novel Anas platyrhynchos avian beta-defensins, upregulated by duck hepatitis virus, with antibacterial and antiviral activities. Molecular Immunology 49(1-2): 84-96. doi: 10.1016/j.molimm.2011.07.019.

Ma, D.Y., Liu, S.W., Han, Z.X., Li, Y.J., and Shan, A.S. 2008. Expression and characterization of recombinant gallinacin-9 and gallinacin-8 in Escherichia coli. Protein Expression and Purification 58(2): 284-291. doi: 10.1016/j.pep.2007.11.017.

Ma, D.Y., Zhang, K.X., Zhang, M.Y., Xin, S.N., Liu, X.L., Han, Z.X., Shao, Y.H., and Liu, S.W. 2012b. Identification, Expression and Activity Analyses of Five Novel Duck Beta-Defensins. Plos One 7(10). doi: 10.1371/journal.pone.0047743.

Ma, D.Y., Zhang, M.Y., Zhang, K.X., Liu, X.L., Han, Z.X., Shao, Y.H., and Liu, S.W. 2013. Identification of three novel avian beta-defensins from goose and their significance in the 
pathogenesis of Salmonella. Molecular Immunology 56(4): 521-529. doi: 10.1016/j.molimm.2013.05.227.

Ma, D.Y., Zhou, C.Y., Zhang, M.Y., Han, Z.X., Shao, Y.H., and Liu, S.W. 2012c. Functional analysis and induction of four novel goose (Anser cygnoides) avian beta-defensins in response to salmonella enteritidis infection. Comparative Immunology Microbiology and Infectious Diseases 35(2): 197-207. doi: 10.1016/j.cimid.2012.01.006.

Marx, F. 2004. Small, basic antifungal proteins secreted from filamentous ascomycetes: a comparative study regarding expression, structure, function and potential application. Applied Microbiology and Biotechnology 65(2): 133-142. doi: 10.1007/s00253-004-1600-z.

Matsuzaki, K., Sugishita, K., Fujii, N., and Miyajima, K. 1995. Molecular-Basis for Membrane Selectivity of an Antimicrobial Peptide, Magainin-2. Biochemistry 34(10): 3423-3429. doi: 10.1021/Bi00010a034.

Mcfarlane, A.S. 1949. Electron Microscopy of Bacteria and Viruses. British Medical Journal 2(4639): 1250-1250.

Meyer, V. 2008. A small protein that fights fungi: AFP as a new promising antifungal agent of biotechnological value. Applied Microbiology and Biotechnology 78(1): 17-28. doi: 10.1007/s00253-007-1291-3.

Meyer, V., and Stahl, U. 2002. New insights in the regulation of the afp gene encoding the antifungal protein of Aspergillus giganteus. Current Genetics 42(1): 36-42. doi: 10.1007/s00294-0020324-9.

Michailidis, G., Avdi, M., and Argiriou, A. 2012. Transcriptional profiling of antimicrobial peptides avian beta-defensins in the chicken ovary during sexual maturation and in response to Salmonella enteritidis infection. Res Vet Sci 92(1): 60-65. doi: 10.1016/j.rvsc.2010.10.010. 
Milona, P., Townes, C.L., Bevan, R.M., and Hall, J. 2007. The chicken host peptides, gallinacins 4, 7, and 9 have antimicrobial activity against Salmonella serovars. Biochemical and Biophysical Research Communications 356(1): 169-174. doi: 10.1016/j.bbrc.2007.02.098.

Oldfield, C.J., Cheng, Y., Cortese, M.S., Brown, C.J., Uversky, V.N., and Dunker, A.K. 2005. Comparing and combining predictors of mostly disordered proteins. Biochemistry 44(6): 1989-2000. doi: 10.1021/bi047993o.

Peng, K., Vucetic, S., Radivojac, P., Brown, C.J., Dunker, A.K., and Obradovic, Z. 2005. Optimizing long intrinsic disorder predictors with protein evolutionary information. J Bioinform Comput Biol 3(1): 35-60. doi: S0219720005000886 [pii].

Peng, Z.L., and Kurgan, L. 2012. Comprehensive comparative assessment of in-silico predictors of disordered regions. Curr Protein Pept Sci 13(1): 6-18. doi: BSP/CPPS/E-Pub/165 [pii].

Porter, E.M., vanDam, E., Valore, E.V., and Ganz, T. 1997. Broad-spectrum antimicrobial activity of human intestinal defensin 5. Infection and Immunity 65(6): 2396-2401.

Powers, J.P.S., and Hancock, R.E.W. 2003. The relationship between peptide structure and antibacterial activity. Peptides 24(11): 1681-1691. doi: 10.1016/j.peptides.2003.08.023.

Redwan, E.M. 2012. Simple, sensitive, and quick protocol to detect less than $1 \mathrm{ng}$ of bacterial lipopolysaccharide. Prep Biochem Biotechnol 42(2): 171-182. doi: 10.1080/10826068.2011.586081.

Redwan, E.M., EL-Fakharany, E.M., Uversky, V.N., and Linjawi, M.H. 2014. Screening the anti infectivity potentials of native $\mathrm{N}$ - and C-lobes derived from the camel lactoferrin against hepatitis C virus. Bmc Complementary and Alternative Medicine 14. doi: 10.1186/14726882-14-219. 
Shin, S.Y., Lee, S.H., Yang, S.T., Park, E.J., Lee, D.G., Lee, M.K., Eom, S.H., Song, W.K., Kim, Y., Hahm, K.S., and Kim, J.I. 2001. Antibacterial, antitumor and hemolytic activities of alphahelical antibiotic peptide, P18 and its analogs. Journal of Peptide Research 58(6): 504-514. doi: 10.1034/j.1399-3011.2001.00934.x.

Soman, S.S., Sivakumar, K.C., and Sreekumar, E. 2010. Molecular dynamics simulation studies and in vitro site directed mutagenesis of avian beta-defensin Apl_AvBD2. BMC Bioinformatics 11 Suppl 1: S7. doi: 10.1186/1471-2105-11-S1-S7.

Sugiarto, H., and Yu, P.L. 2004. Avian antimicrobial peptides: the defense role of beta-defensins. Biochemical and Biophysical Research Communications 323(3): 721-727. doi: 10.1016/j.bbrc.2004.08.162.

Tamura, K., and Nei, M. 1993. Estimation of the number of nucleotide substitutions in the control region of mitochondrial DNA in humans and chimpanzees. Mol Biol Evol 10(3): 512-526.

Tamura, K., Stecher, G., Peterson, D., Filipski, A., and Kumar, S. 2013. MEGA6: Molecular Evolutionary Genetics Analysis version 6.0. Mol Biol Evol 30(12): 2725-2729. doi: 10.1093/molbev/mst197.

Thouzeau, C., Le Maho, Y., Froget, G., Sabatier, L., Le Bohec, C., Hoffmann, J.A., and Bulet, P. 2003. Spheniscins, avian beta-defensins in preserved stomach contents of the king penguin, Aptenodytes patagonicus. Journal of Biological Chemistry 278(51): 51053-51058. doi: 10.1074/jbc.M306839200.

Uversky, V.N., Gillespie, J.R., and Fink, A.L. 2000. Why are "natively unfolded" proteins unstructured under physiologic conditions? Proteins 41(3): 415-427. doi: 10.1002/10970134(20001115)41:3<415::AID-PROT130>3.0.CO;2-7 [pii].

van Dijk, A., Veldhuizen, E.J.A., and Haagsman, H.P. 2008. Avian defensins. Veterinary Immunology and Immunopathology 124(1-2): 1-18. doi: 10.1016/j.vetimm.2007.12.006. 
van Dijk, A., Veldhuizen, E.J.A., Kalkhove, S.I.C., Tjeerdsma-van Bokhoven, J.L.M., Romijn, R.A., and Haagsman, H.P. 2007. The beta-defensin gallinacin-6 is expressed in the chicken digestive tract and has antimicrobial activity against food-borne pathogens. Antimicrobial Agents and Chemotherapy 51(3): 912-922. doi: 10.1128/Aac.00568-06.

Veldhuizen, E.J.A., Rijnders, M., Claassen, E.A., van Dijk, A., and Haagsman, H.P. 2008. Porcine beta-defensin 2 displays broad antimicrobial activity against pathogenic intestinal bacteria. Molecular Immunology 45(2): 386-394. doi: 10.1016/j.molimm.2007.06.001.

Wang, R.Q., Ma, D.Y., Lin, L.J., Zhou, C.Y., Han, Z.X., Shao, Y.H., Liao, W.Y., and Liu, S.W. 2010. Identification and characterization of an avian beta-defensin orthologue, avian betadefensin 9, from quails. Applied Microbiology and Biotechnology 87(4): 1395-1405. doi: 10.1007/s00253-010-2591-6.

Wang, Y.P., Lu, Z.K., Feng, F.F., Zhu, W., Guang, H.J., Liu, J.Z., He, W.Y., Chi, L.L., Li, Z., and Yu, H.N. 2011. Molecular cloning and characterization of novel cathelicidin-derived myeloid antimicrobial peptide from Phasianus colchicus. Developmental and Comparative Immunology 35(3): 314-322. doi: 10.1016/j.dci.2010.10.004.

Xiao, Y., Hughes, A.L., Ando, J., Matsuda, Y., Cheng, J.F., Skinner-Noble, D., and Zhang, G. 2004. A genome-wide screen identifies a single beta-defensin gene cluster in the chicken: implications for the origin and evolution of mammalian defensins. BMC genomics 5(1): 56. doi: 10.1186/1471-2164-5-56.

Yacoub, H.A., Elazzazy, A.M., Abuzinadah, O.A.H., Al-Hejin, A.M., Mahmoud, M.M., and Harakeh, S.M. 2015. Antimicrobial activities of chicken beta-defensin (4 and 10) peptides against pathogenic bacteria and fungi. Frontiers in Cellular and Infection Microbiology 5. doi: 10.3389/Fcimb.2015.00036. 
Yacoub, H.A., Galal, A., Fathi, M.M., El Fiky, S.A., and Ramadan, H.A.I. 2011. Association between candidate genes of innate immunity, gallinacin genes and resistance to Marek's disease in chicken. International Journal of Poultry Science 10(8): 656-661.

Yu, P.L., Choudhury, S.D., and Ahrens, K. 2001. Purification and characterization of the antimicrobial peptide, ostricacin. Biotechnology Letters 23(3): 207-210. doi: 10.1023/A:1005623806445.

Zasloff, M. 2002. Antimicrobial peptides of multicellular organisms. Nature 415(6870): 389-395. doi: $10.1038 / 415389 a$.

Zhang, G., and Sunkara, L.T. 2014. Avian antimicrobial host defense peptides: from biology to therapeutic applications. Pharmaceuticals 7(3): 220-247. doi: 10.3390/ph7030220.

Zhang, M., Zhou, C., Han, Z., Shao, T., Liu, S., and Ma, D. 2011. [Isolation, identification and bioactivity characterization of goose avian beta-defensin 3]. Sheng Wu Gong Cheng Xue Bao 27(12): 1711-1721.

Zhang, M.Y., Zhang, K.X., Xin, S.N., Han, Z.X., Shao, Y.H., Liu, X.L., Liu, S.W., and Ma, D.Y. 2012. Preliminary exploration of the signal transduction mechanisms of the goose beta defensin 1 resistance to Salmonella enteritidis infection mediated by toll-like receptor 4 . Acta Veterinary et Zootechnica Sinica 43: 1938-1948.

Zhao, C., Nguyen, T., Liu, L., Sacco, R.E., Brogden, K.A., and Lehrer, R.I. 2001. Gallinacin-3, an inducible epithelial beta-defensin in the chicken. Infect Immun 69(4): 2684-2691. doi: 10.1128/IAI.69.4.2684-2691.2001.

Zucht, H.D., Grabowsky, J., Schrader, M., Liepke, C., Jurgens, M., Schulz-Knappe, P., and Forssmann, W.G. 1998. Human beta-defensin-1: A urinary peptide present in variant molecular forms and its putative functional implication. Eur J Med Res 3(7): 315-323. 
Table 1. Primers and peptide sequences of chicken $\beta$-defensin- 9 gene

\begin{tabular}{c|c|c}
\hline mRNA & Forward Primer & Reverse Primer \\
\hline $\begin{array}{c}\text { AvBD-9-RT- } \\
\text { PCR }\end{array}$ & 5'- atgAGGAATCCTTTTCTTCCTTGTTGC -3' & 5'- TTAGGAGCTAGGTGCCCATTTGCAGC -3' \\
\hline $\begin{array}{c}\text { AvBD-9-RT- } \\
\text { PCR }\end{array}$ & 5'- GCTTACAGCCAAGGAGATGCT-3' & 5'-GGAGCTAGGTGCCCATTTGCA -3' \\
\hline GAPDH \\
$\begin{array}{c}(\text { Achanta et al. } \\
\text { 2012)) }\end{array}$
\end{tabular}

RT-PCR: real time PCR; GAPDH: glyceraldehyde-3-phosphate dehydrogenase; sAvBD-9: synthetic chicken $\beta$-defensin-9. 
Table.2. The antimicrobial activities of synthetic chicken $\beta$-defensin-9- derived peptide

\begin{tabular}{|c|c|c|c|c|}
\hline Organisms & & & Tetracycline & \\
\hline Bacteria & $\mathrm{MIC}(\mu \mathrm{g} / \mathrm{ml})$ & $\begin{array}{l}\text { MBC or MFC } \\
(\mu \mathrm{g} / \mathrm{ml})\end{array}$ & $\begin{array}{l}\text { MBC or MFC } \\
(\mu \mathrm{g} / \mathrm{ml})\end{array}$ & $\mathrm{MIC}(\mu \mathrm{g} / \mathrm{ml})$ \\
\hline $\begin{array}{l}\text { S. bovis } \\
\text { ATCC (49147) }\end{array}$ & $6.25 \pm 6.9$ & $12.5 \pm 1.7$ & $25 \pm 0.0$ & $12.5 \pm 3.46$ \\
\hline $\begin{array}{l}\text { S. epidermidis } \\
\text { ATCC (12228) }\end{array}$ & $6.25 \pm 3.0$ & $12.5 \pm 1.7$ & $12.5 \pm 0.0$ & $12.5 \pm 1.73$ \\
\hline $\begin{array}{l}\text { S. aureus MRSA } \\
\text { ATCC (43330) }\end{array}$ & $6.25 \pm 3.0$ & $6.25 \pm 1.7$ & $25 \pm 1.73$ & $25 \pm 0.0$ \\
\hline $\begin{array}{l}\text { E. faecalis } \\
\text { ATCC (29212) }\end{array}$ & $6.25 \pm 1.53$ & $6.25 \pm 0.0$ & $25 \pm 0.0$ & $6.25 \pm 0.0$ \\
\hline $\begin{array}{l}\text { M. luteus } \\
\text { ATCC (49732) }\end{array}$ & $6.25 \pm 1.15$ & $12.5 \pm 1.73$ & $12.5 \pm 0.0$ & $6.25 \pm 0.0$ \\
\hline $\begin{array}{l}\text { E. coli } \\
\text { ATCC (25922) }\end{array}$ & $6.25 \pm 1.73$ & $12.5 \pm 1.73$ & $12.5 \pm 1.73$ & $6.25 \pm 0.0$ \\
\hline $\begin{array}{l}P . \text { aeruginosa } \\
\text { ATCC (27853) }\end{array}$ & $6.25 \pm 6.93$ & $12.5 \pm 1.73$ & $12.5 \pm 1.73$ & $12.5 \pm 1.73$ \\
\hline $\begin{array}{l}\text { S. typhimurium } \\
\text { ATCC (14028) }\end{array}$ & $6.25 \pm 3.0$ & $12.5 \pm 0.0$ & $25 \pm 0.0$ & $12.5 \pm 0.0$ \\
\hline $\begin{array}{l}\text { K. pneumonia } \\
\text { ATCC (700603) }\end{array}$ & $6.25 \pm 3.46$ & $6.25 \pm 0.0$ & $25 \pm 0.0$ & $6.25 \pm 0.0$ \\
\hline $\begin{array}{l}\text { Sh. sonnei } \\
\text { ATCC (25931) }\end{array}$ & $3.2 \pm 1.73$ & $6.25 \pm 1.7$ & $12.5 \pm 1.0$ & $6.25 \pm 0.0$ \\
\hline Fungi species & & 30 & Ketoconazole & \\
\hline $\begin{array}{l}\text { C. albicans } \\
\text { ATCC (10231) }\end{array}$ & $6.25 \pm 1.7$ & $6.25 \pm 1.73$ & $10 \pm 0.0$ & $10 \pm 0.0$ \\
\hline A. flavus & $3.2 \pm 0.0$ & $3.2 \pm 1.73$ & $10 \pm 0.0$ & $10 \pm 0.0$ \\
\hline A. niger & $3.2 \pm 0.58$ & $6.25 \pm 0.58$ & $10 \pm 0.0$ & $>10 \pm 0.0$ \\
\hline
\end{tabular}

sAvBD-9: synthetic chicken $\beta$-defensin-9; MIC: Minimal inhibition concentration; MBC: Minimal bacterial concentration; MFC: Minimal Fungal concentration.

All experiments were performed at least 3-times in doublets. 


\section{Figure legends}

Figure 1. CLASTALW 2.0.12 multiple sequence alignment based on $\beta$-defensin- 9 of local chicken (KR136304) and other avian species [(Anas platyrhynchos (mallard Duck, EF431957), Coturnix coturnix (quail, GQ985499), Anser cygnoides (goose, HQ909023)].

Figure 2. Phylogenetic relationship among $\beta$-desensin-9 of Saudi chicken, other related avian species and some of mammalian $\beta$-defensin-9. The phylogeny was inferred by using the Maximum likelihood method based on the Tamura-Nei model.

Figure 3. Amino acids sequence alignment of $\beta$-defensin-9 of Saudi chicken with related avian species. The signal and mature peptides of $\beta$-defensin- 9 are underlined and the six conserved cysteines residues (C) are underlined in bold. The differences among avian species are highlighted in yellow.

Figure 4. Evaluating intrinsic disorder propensity of different defensins using the pre-residue disorder predictor PONDR® VSL2 (A) and a binary disorder predictor CH-plot (B).

Figure 5. The expression patterns of $\beta$-defenisn- 9 in local chicken in different tissues. The expression levels were normalized to glyceraldehyde-3-phosphate dehydrogenase GAPDH as a reference gene. All assays were performed in three independent experiments and each point is the mean $\pm \mathrm{SE}$. The baseline is being 1 or -1 , since the range is defined to be between $+\mathrm{X}$ and +1 for the up-regulated genes, -1 and $-\mathrm{X}$ for the down-regulated genes. 
Figure 6. The kinetic inactivation of synthetic chicken $\beta$-defensin-9 peptide (sAvBD) against MRSA, E. coli and C. albicans species. All assays were performed in three independent experiments and each point is the mean $\pm \mathrm{SE}(P<0.001)$.

Figure 7. Effects of salinity on the antibacterial activity of synthetic chicken $\beta$-defensin-9derived peptide (sAvBD9) against E.coli. All assays were performed in three independent experiments and each point is the mean $\pm \mathrm{SE}(P<0.001)$.

Figure 8. Heamolytic activities of synthetic chicken $\beta$-defensin-9-derived peptide (sAvBD-9) using the freshly isolated chicken erythrocytes. All assays were performed in three independent experiments and each point is the mean $\pm \mathrm{SE}$.

Figure 9. TEM micrographs of synthetic avian $\beta$-defensin-9 that exploit its size as marked by arrows.

Figure 10. TEM micrographs of bacteria treated with synthetic avian $\beta$-defensin-9 a) $S$. aureus MRSA ATCC (43330) as a control, bar $1 \mu \mathrm{m}$; b) S. aureus MRSA treated with $2.5 \times \mathrm{MIC}$, bar $0.2 \mu \mathrm{m}$; c) $S$. aureus $M R S A$ treated with $5 \times \mathrm{MIC}$, bar $0.2 \mu \mathrm{m}$. Here, the arrows point to the damage of the bacterial cell membrane that promotes the cell lysis and leakage of the cytoplasmic continents. 
Figure 11. TEM micrographs of bacteria treated with synthetic avian $\beta$-defensin-9 a) $S$. sonnei ATCC (25931) as a control, bar $0.2 \mu \mathrm{m}$; b) $S$. sonnei treated with $2.5 \times \mathrm{MIC}$, bar $0.5 \mu \mathrm{m}$; c) $S$. sonnei treated with $5 \times \mathrm{MIC}$, bar $0.5 \mu \mathrm{m}$. Here, the arrows point the damage of the bacterial cell membrane that promotes the cell lysis and leakage of the cytoplasmic continents. 


\begin{tabular}{|c|c|c|c|}
\hline Local & Chicken & АTGAGAATCCTTTTCTTCCTTGTTGCTGTTCTCTTCTTCCTCTTCCAGGCTGCTCCAGCT & 60 \\
\hline Duck & & ATGAGAATCCTTTTCTTCCTTGTTGCTGTTCTCTTCTTCCTCTTCCAGGCTGCTCCAGCT & 60 \\
\hline Quail & & ATGAGAATCCTTTTCTTCCTTGTTGCTGTTCTCTTCTTCCTCTTCCAGGCTGCTCCAGCT & 60 \\
\hline Goose & & 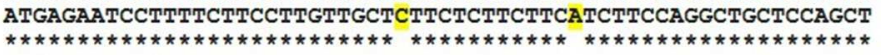 & 60 \\
\hline Local & Chicken & TACAGCCAAGAAGACGCTGACACCTTAGCATGCAGGCAGAGCCACGGCTCCTGCTCTTTT & 120 \\
\hline Duck & & TACAGCCAAGAAGACGCTGACACCTTAGCATGCAGGCAGAGCCACGGCTCCTGCTCTTTT & 120 \\
\hline Quail & & TACAGCCAAGAAGACCCTGACACCTTAGCATGCCGGCAGGGCCATGGCTCCTGCTCTTTC & 120 \\
\hline \multirow[t]{2}{*}{ Goose } & & TACAGCCAAGGAGATGCTGACACCTTGGCATGCCGGCAAAACCGTGGCTCCTGCTCTTTT & 120 \\
\hline & & 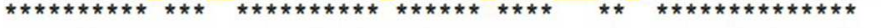 & \\
\hline Local & Chicken & GTTGCATGCCGTGCTCCTTCAGTTGACATTGGGACCTGCCGTGGTGGGAAGCTGAAATGC & 180 \\
\hline Duck & & GTTGCATGCCGTGCTCCTTCAGTTGACATTGGGACCTGCCGTGGTGGGAAGCTGAAATGC & 180 \\
\hline Quail & & GTTGCATGCCGTGCTCCTTCAGTTGACATTGGGACCTGCCGTGGTGGGAAGCTGAAATGC & 180 \\
\hline Goose & & 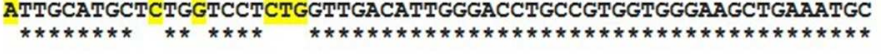 & 180 \\
\hline Local & Chicken & TGCAAATGGGCACCCAGCTCCTAA 204 & \\
\hline Duck & & TGCAAATGGGCACCTAGCTCCTAA 204 & \\
\hline Quail & & TGCAAATGGGCACCTAGCTCCTAA 204 & \\
\hline Goose & & $\begin{array}{l}\text { TGCAAATGGGCACCTAGCTCCTAA } 204 \\
* * * * * * * * * * * * * * * * * * * * * *\end{array}$ & \\
\hline
\end{tabular}

Figure 1

$152 \times 73 \mathrm{~mm}(150 \times 150 \mathrm{DPI})$ 


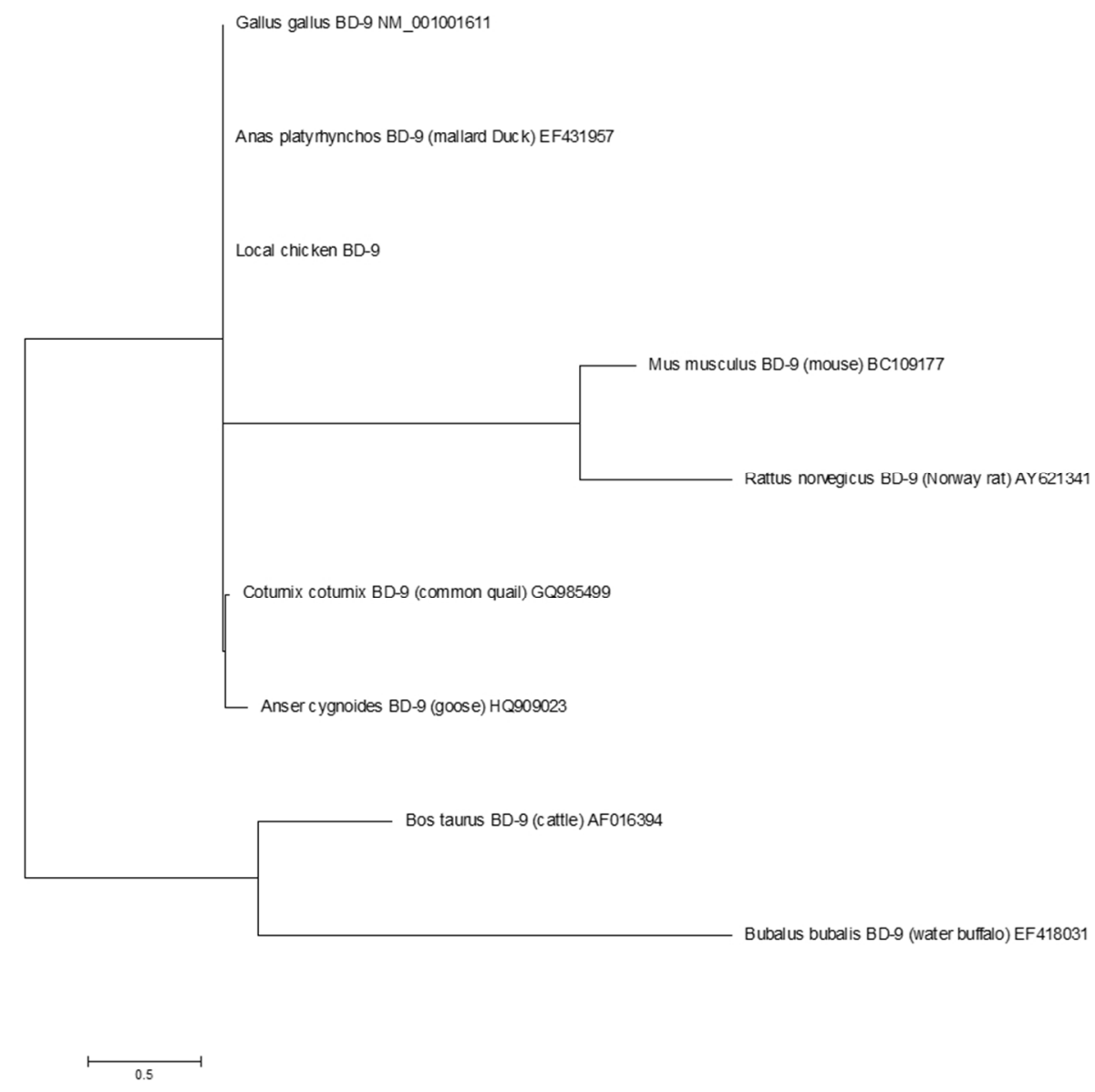

Figure 2

$82 \times 78 \mathrm{~mm}(300 \times 300$ DPI $)$ 


\begin{tabular}{|c|c|}
\hline Local Chicken & MRILFFLVAVLFFLEQAAPAYSQEDADTLACRQSHGSCSFVACRAPSVDIGTCRGGKLKC 60 \\
\hline Duck & 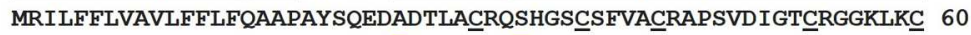 \\
\hline Quail & MRILFFLVAVLFFLFQAAPAYSQEDPDTLACRQGHGSCSSFVACRAPSVDIGTCRGGKLK $\underline{C}$ \\
\hline \multirow[t]{2}{*}{ Goose } & MRILFFLVALLFFIFQAAPAYSQGDADTLACRQNRGSCESFIACSGPLVDIGTCRGGKLIKC \\
\hline & 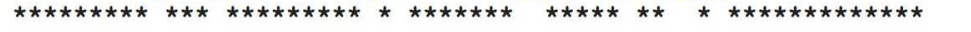 \\
\hline Local Chicken & CKWAPSS 67 \\
\hline Duck & CKKWAPSS 67 \\
\hline Quail & CKKWAPSS 67 \\
\hline \multirow[t]{2}{*}{ Goose } & CKKWAPSS 67 \\
\hline & 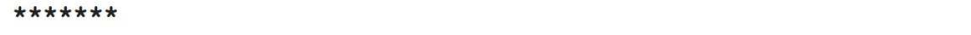 \\
\hline
\end{tabular}

Figure 3

$324 \times 94 \mathrm{~mm}(150 \times 150$ DPI $)$

https://mc06.manuscriptcentral.com/bcb-pubs 

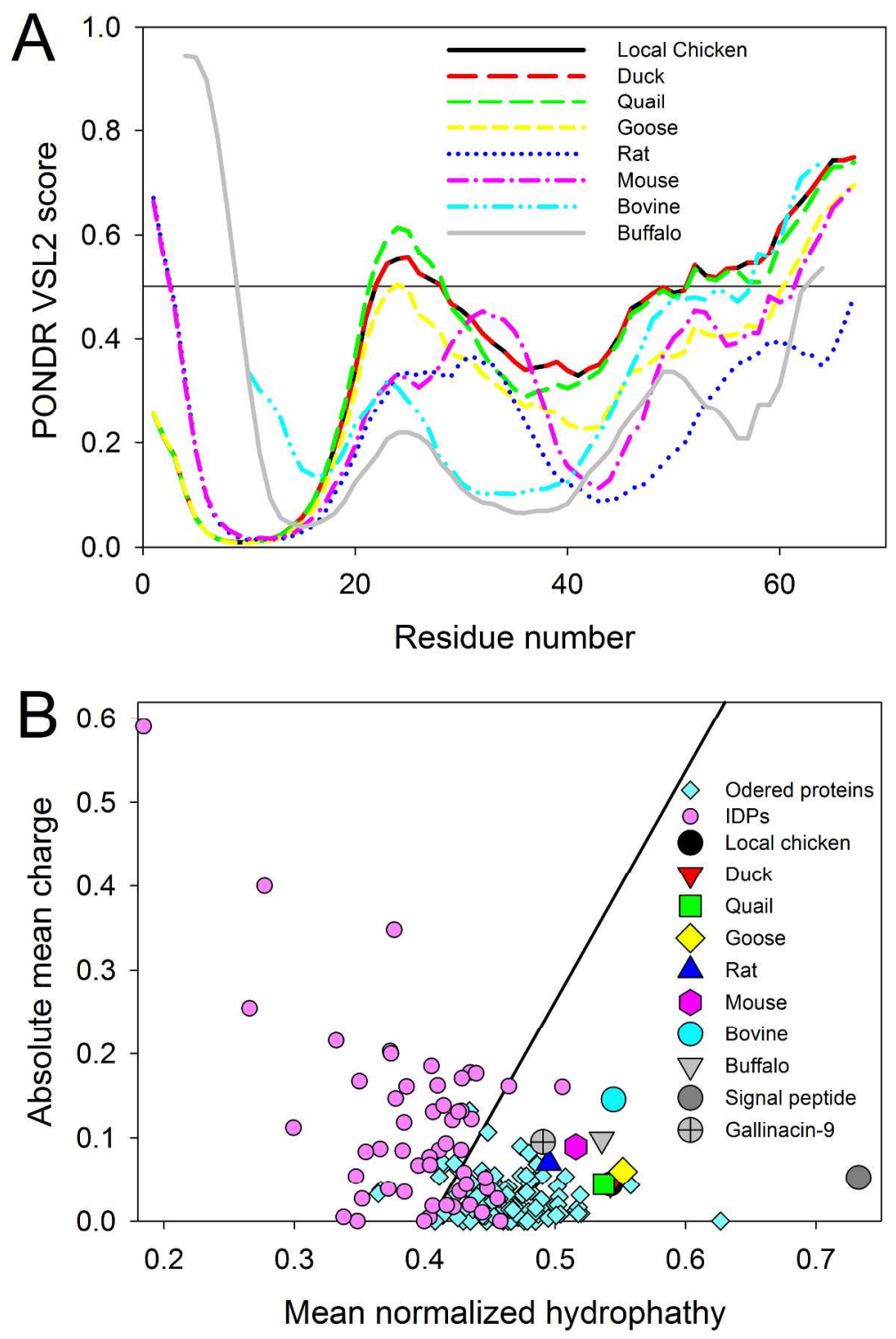

Figure 4

$237 \times 358 \mathrm{~mm}(300 \times 300 \mathrm{DPI})$ 


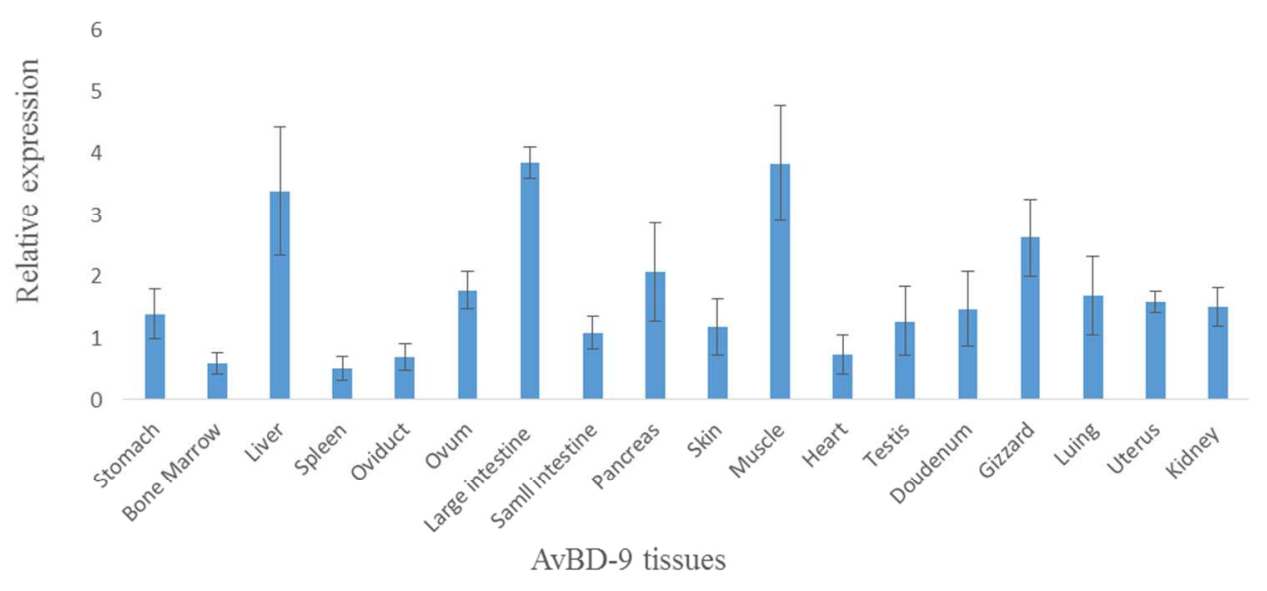

Figure 5

$88 \times 45 \mathrm{~mm}$ (300 x 300 DPI) 


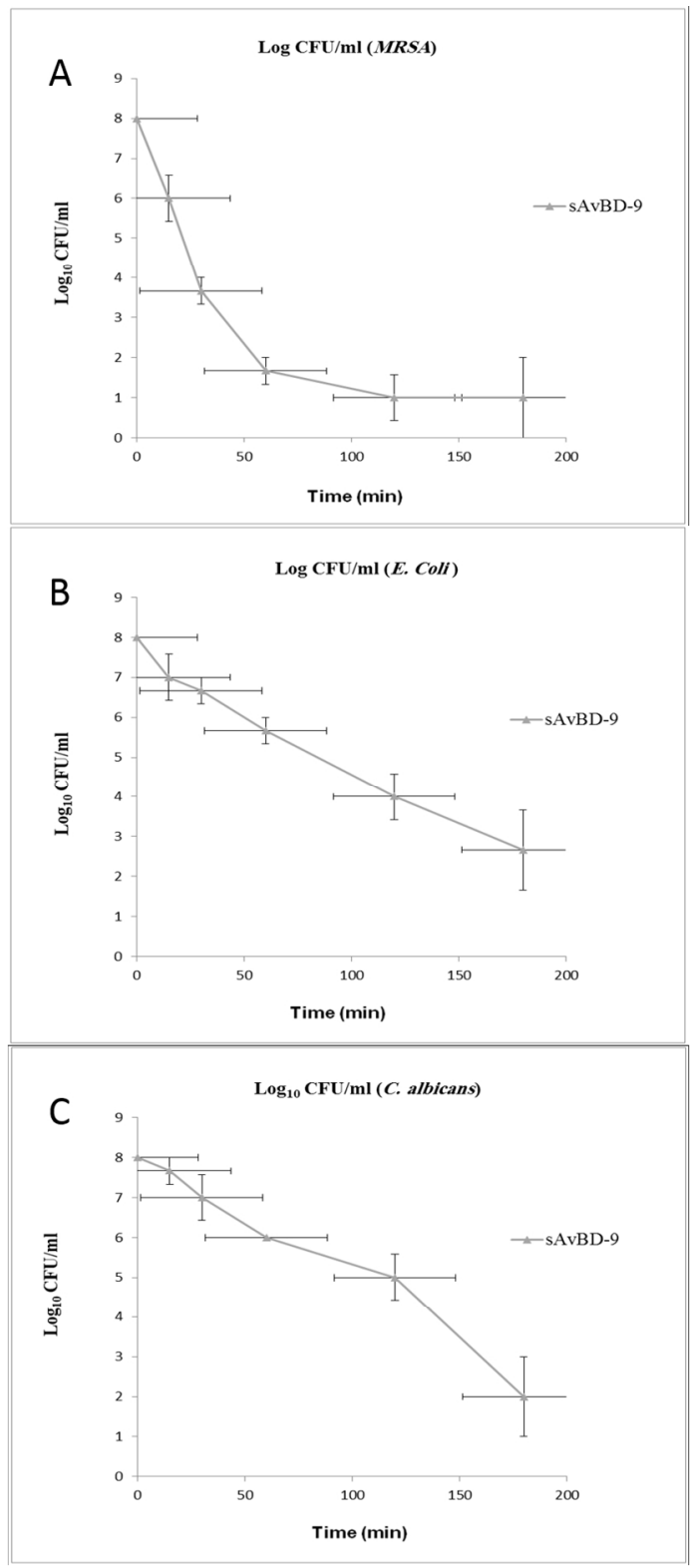

Figure 6 $140 \times 320 \mathrm{~mm}(150 \times 150 \mathrm{DPI})$ 


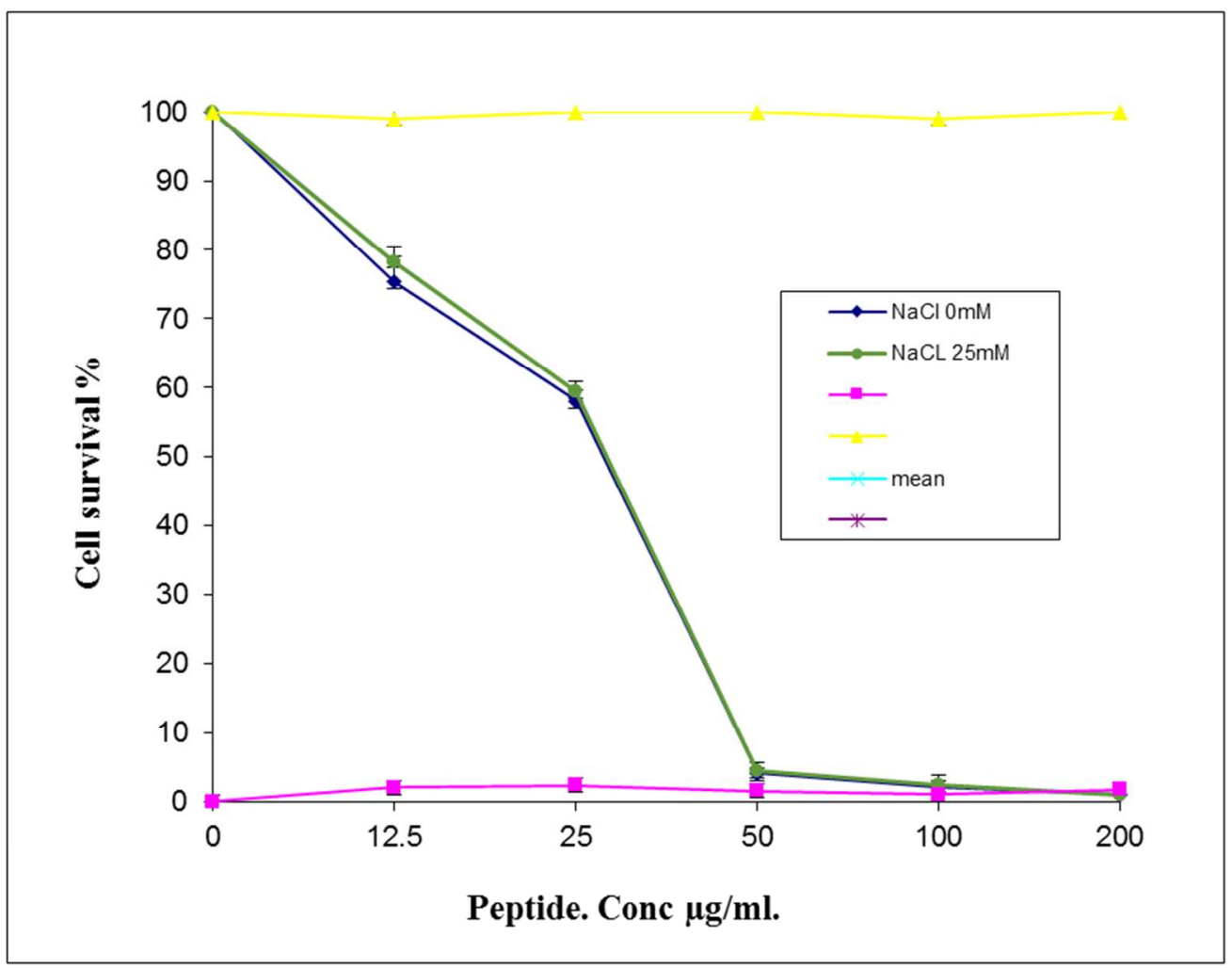

Figure 7

$73 \times 57 \mathrm{~mm}(300 \times 300 \mathrm{DPI})$ 


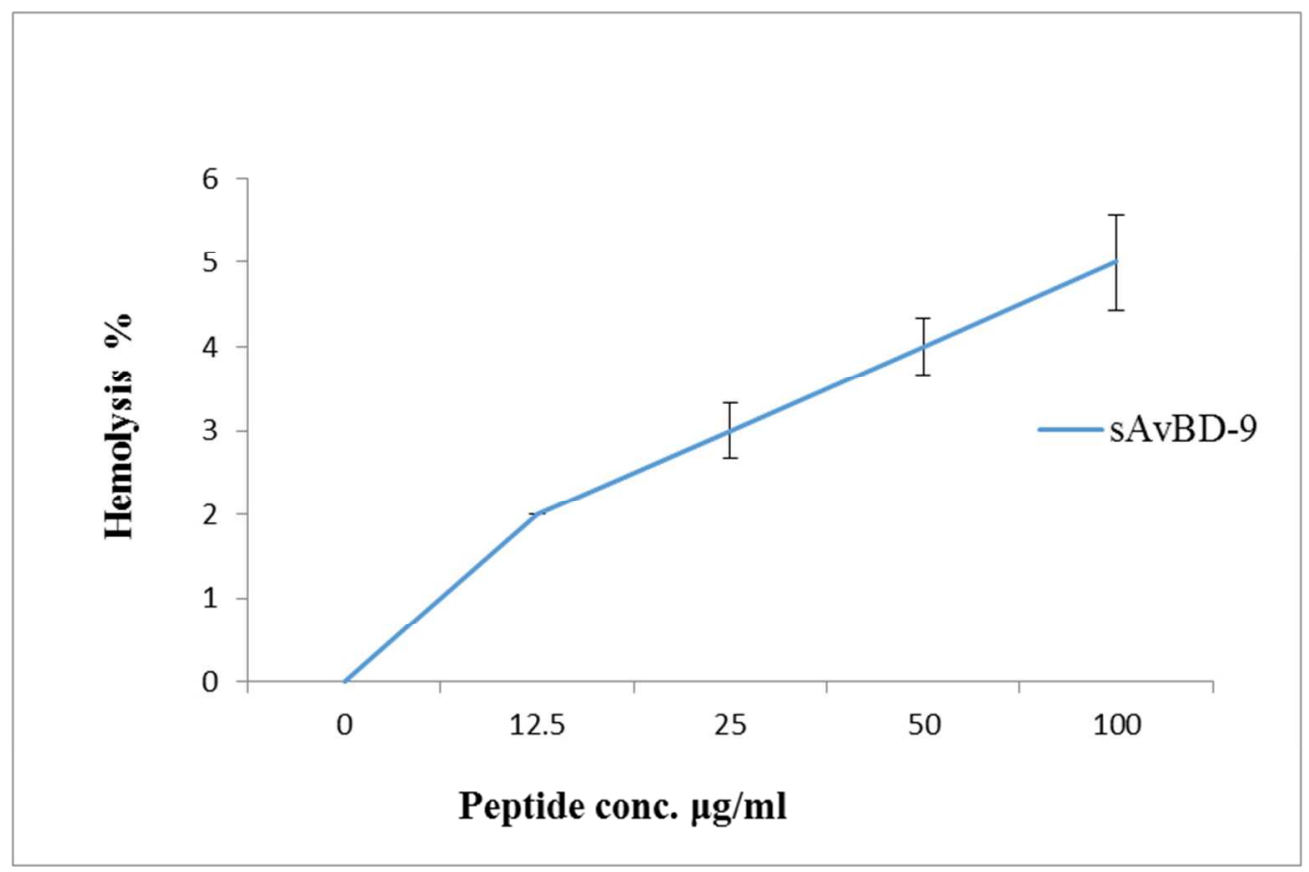

Figure 8

$70 \times 46 \mathrm{~mm}$ (300 x 300 DPI) 


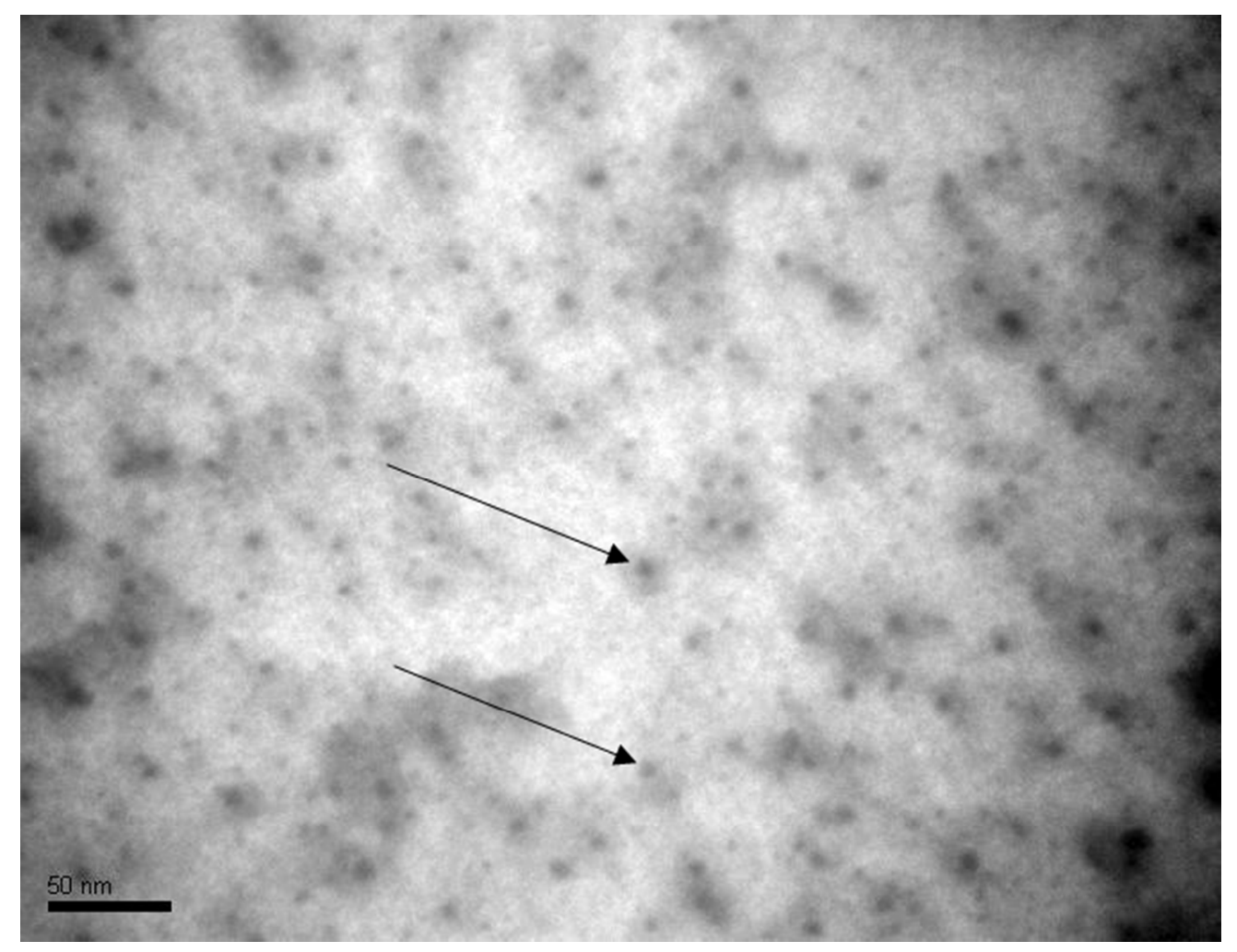

Figure 9

$56 \times 44 \mathrm{~mm}(300 \times 300$ DPI) 

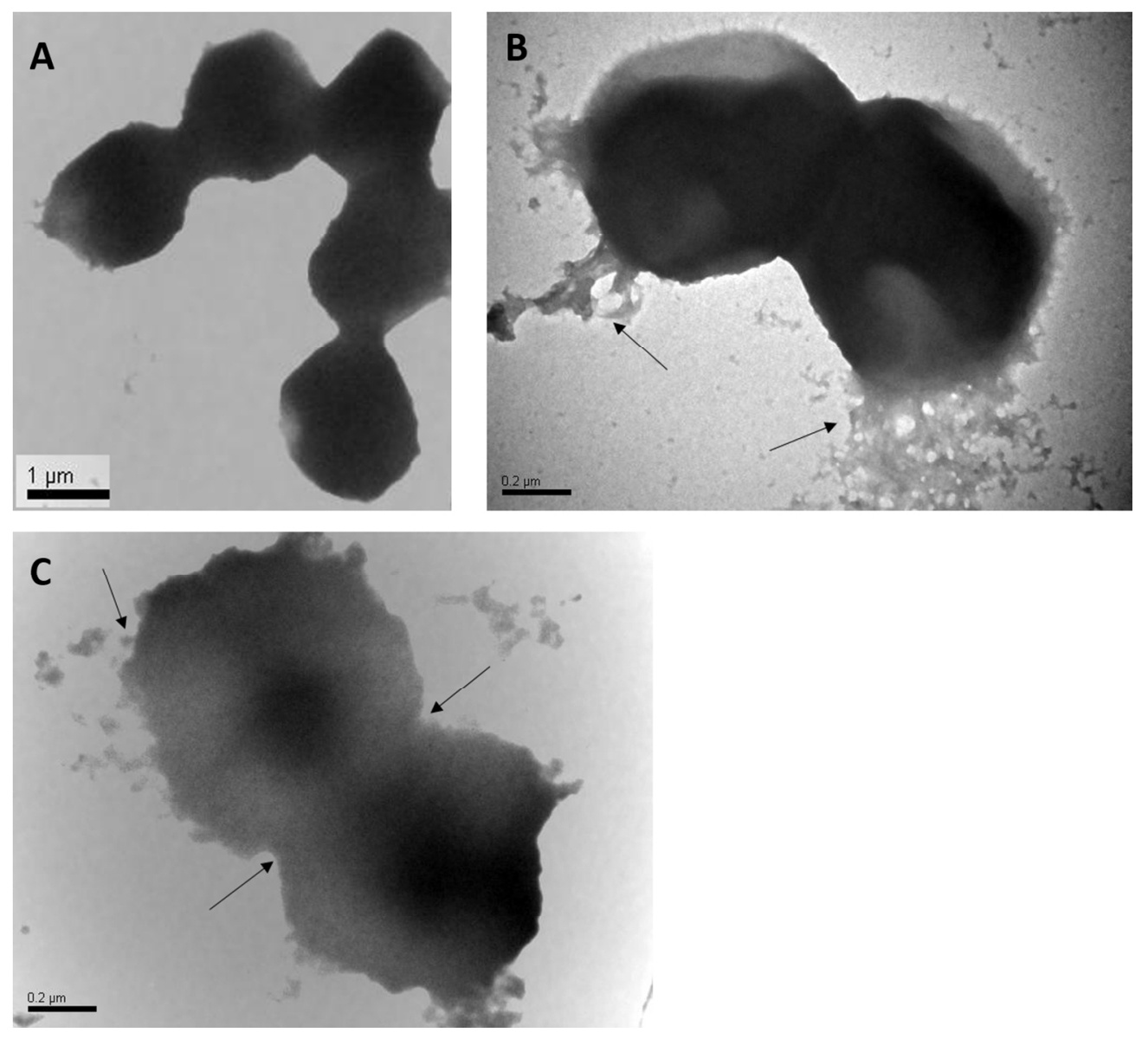

Figure 10

$413 \times 373 \mathrm{~mm}(96 \times 96 \mathrm{DPI})$ 


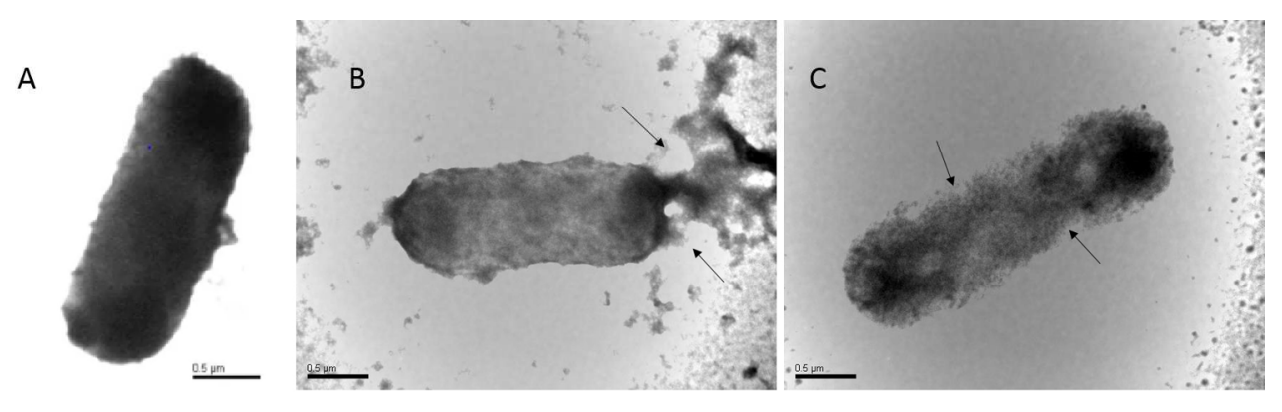

Figure 11

$525 \times 160 \mathrm{~mm}(96 \times 96$ DPI) 